\title{
The Perron Gold Deposit, Archean Abitibi Belt, Canada: Exceptionally High-Grade Mineralization Related to Higher Gold-Carrying Capacity of Hydrocarbon-Rich Fluids
}

\author{
Damien Gaboury ${ }^{1, *(\mathbb{D}}$, Dominique Genna ${ }^{1,2}{ }^{\mathbb{D}}$, Jacques Trottier $^{3}$, Maxime Bouchard ${ }^{4}$, Jérôme Augustin 4 \\ and Kelly Malcolm ${ }^{3}$ \\ 1 Laboratoire de Métallogénie Expérimentale et Quantitative (LAMEQ), Université du Québec à \\ Chicoutimi (UQAC), Chicoutimi, QC G7H 2B1, Canada; dominique.genna@uqac.ca \\ 2 Consortium de Recherche en Exploration Minérale (CONSOREM), Université du Québec à \\ Chicoutimi (UQAC), Chicoutimi, QC G7H 2B1, Canada \\ 3 Amex Exploration Inc., Montréal, QC H2Y 2P5, Canada; jacques_trottier@msn.com (J.T.); \\ kelly.malcolm@amexexploration.com (K.M.) \\ 4 Laurentia Exploration Inc., Jonquière, QC G7X 0M1, Canada; maxime.b@laurentiaexploration.com (M.B.); \\ jerome.a@laurentiaexploration.com (J.A.) \\ * Correspondence: dgaboury@uqac.ca
}

Citation: Gaboury, D.; Genna, D.; Trottier, J.; Bouchard, M.; Augustin, J.; Malcolm, K. The Perron Gold Deposit, Archean Abitibi Belt, Canada: Exceptionally High-Grade Mineralization Related to Higher Gold-Carrying Capacity of Hydrocarbon-Rich Fluids. Minerals 2021, 11, 1066. https://doi.org/ $10.3390 / \min 11101066$

Academic Editors: Antonia Cepedal and Mercedes Fuertes-Fuente

Received: 26 June 2021

Accepted: 24 September 2021

Published: 29 September 2021

Publisher's Note: MDPI stays neutral with regard to jurisdictional claims in published maps and institutional affiliations.

Copyright: (C) 2021 by the authors Licensee MDPI, Basel, Switzerland. This article is an open access article distributed under the terms and conditions of the Creative Commons Attribution (CC BY) license (https:// creativecommons.org/licenses/by/ $4.0 /)$.
Abstract: The Perron deposit, an Archean orogenic gold deposit located in the Abitibi belt, hosts a quartz vein-type gold-bearing zone, known as the high-grade zone (HGZ). The HGZ is vertically continuous along $>1.2 \mathrm{~km}$, and is exceptionally rich in visible gold throughout its vertical extent, with grades ranging from 30 to $500 \mathrm{ppm}$. Various hypotheses were tested to account for that, such as: (1) efficient precipitating mechanisms; (2) gold remobilization; (3) particular fluids; (4) specific gold sources for saturating the fluids; and (5) a different mineralizing temperature. Host rocks recorded peak metamorphism at $\sim 600^{\circ} \mathrm{C}$ based on an amphibole geothermometer. Visible gold is associated with sphalerite $(<5 \%)$ which precipitated at $370{ }^{\circ} \mathrm{C}$, based on the sphalerite GGIMFis geothermometer, during late exhumation of verticalized host rocks. Pyrite chemistry analyzed by LAICP-MS (Laser Ablation Inductively Coupled Plasma Mass Spectrometry) is comparable to classical orogenic gold deposits of the Abitibi belt, without indication of a possible magmatic fluid and gold contribution. Comparison of pyrite trace element signatures for identifying a potential gold source was inconclusive to demonstrate that primary base-metal rich volcanogenic gold mineralization, dispersed in the host rhyolitic dome, could be the source for the later formation of the HGZ. Rather, nodular pyrites in graphitic shales, sharing similar trace element signatures with pyrite of the HGZ, are considered a potential source. The most striking outcome is the lack of water in the mineralizing fluids, implying that gold was not transported under aqueous complexes, even if fugacity of sulfur $(-6)$ and oxygen $(-28)$, and $\mathrm{pH}(\sim 7)$ are providing the best conditions at a temperature of $350{ }^{\circ} \mathrm{C}$ for solubilizing gold in water. Fluid inclusions, analyzed by solid-probe mass spectrometry, are rather comparable to fossil gas composed mostly of hydrocarbons (methane and ethane and possibly butane and propane and other unidentified organic compounds), rich in $\mathrm{CO}_{2}$, with $\mathrm{N}_{2}$ and trace of $\mathrm{Ar}, \mathrm{H}_{2} \mathrm{~S}$, and He. It is interpreted that gold and zinc were transported as hydrocarbon-metal complexes or as colloidal gold nanoparticles. The exceptional high content of gold and zinc in the HGZ is thus explained by the higher transporting capacity of these unique mineralizing fluids.

Keywords: LA-ICP-MS; fluid inclusion volatile composition; hydrocarbon-rich fluids; high-grade gold deposit; sphalerite GGIMFis geothermometer; amphibole thermobarometry

\section{Introduction}

The Perron project, located in the northern part of the Abitibi belt, Québec, Canada, is an exceptionally high-grade gold Archean orogenic quartz vein-type system. It is currently 
under extensive drilling by Amex Exploration Inc (Montréal, QC, Canada). The high-grade zone (HGZ) is characterized by coarse visible gold disseminated in quartz veins and in association with sphalerite, locally reaching $\sim 5 \%$ of the modal composition of quartz veins. Gold grades are commonly $>30 \mathrm{~g} / \mathrm{t}$ Au with several assays above $500 \mathrm{~g} / \mathrm{t}$ Au. Typical gold grades for orogenic gold deposits formed by low salinity, $\mathrm{CO}_{2}$-bearing aqueous and neutral fluids are in the range of 4 to $8 \mathrm{~g} / \mathrm{t} \mathrm{Au} \mathrm{[1].}$

Archean high-grade gold deposits have been previously documented, such as in the Red Lake district, Ontario, Canada. However, high-grade zones correspond to late structural remobilization as gold occupies crosscutting features in the host quartz and crosscutting dykes [2]. In the present case, high-grade gold concentrations appear to be an inherent feature of the vein system, because: (1) visible gold is disseminated in the quartz veins; (2) visible gold is intimately associated with sphalerite; and (3) high-grade gold values are coherently distributed along a steeply plunging $>1.2-\mathrm{km}$-long ore shoot.

Various hypotheses are tested below to account for such a primary gold enrichment, such as: (1) very efficient gold precipitating mechanisms; (2) remobilization mechanisms; (3) mineralizing fluids with higher solubility for Au and $\mathrm{Zn}$; (4) mineralizing fluids saturated in $\mathrm{Au}$ and $\mathrm{Zn}$ gained from primary gold-bearing volcanogenic ore; and (5) a different temperature from what it is expected for orogenic gold deposits. Trace elements from sulfides analyzed by LA-ICP-MS, volatile composition and petrography of fluid inclusions, and geothermometric data from amphibole and sphalerite are used to address these hypotheses. It is interpreted that the exceptionally high content of gold and zinc is related to the higher transporting capacity of these unusual fluids by hydrocarbon-metal complexes and by colloidal gold nanoparticles.

\section{Regional and Local Geology}

The 2.8 to $2.6 \mathrm{Ga}$ Abitibi greenstone belt, spanning the Ontario-Quebec border, is mostly composed of mafic to felsic volcanic, with lesser ultramafic rocks (e.g., [3,4]) injected by syn-volcanic to late-tectonic intrusive bodies [5]. It is well known for its world-class endowment of orogenic gold [6,7] and VMS deposits [8,9].

The Perron project is located close to the mining town of Normétal (Figure 1). The 4-km-thick and 60-km-long Normétal Volcanic Complex (NVC) is composed predominately of rhyolite with minor basalt, andesite, dacite, and volcano-sedimentary rocks [10]. The NVC was dated at $2727.7+2.6 /-2.1$ Ma [11], but more recent radiometric dating indicate that the central and western parts are circa 2725 to $2720 \mathrm{Ma}$ [12]. The homoclinal NVC is tilted vertically with a southward younging direction. A volcano-sedimentary horizon, defining the end of five volcanic cycles associated with the evolution of two principal calderas (Western and Central [11]), hosts two past producing massive sulfide deposits: Normétal (11 Mt grading $5.12 \% \mathrm{Zn}, 2.15 \% \mathrm{Cu}, 0.549 \mathrm{~g} / \mathrm{t} \mathrm{Au}$ and $45.25 \mathrm{~g} / \mathrm{t} \mathrm{Ag:} \mathrm{[13])} \mathrm{and}$ Normetmar $(160,000 \mathrm{t}$ at $12.6 \% \mathrm{Zn})$. It is referred to as the Normétal mine horizon. The Beaupré rhyolitic dome occurs above the volcano-sedimentary horizon and above the Western caldera. It is internally interpreted as a large submittal dome (Figure 1), stratigraphically coherent with the NVC, as supported by the recent $\mathrm{U}-\mathrm{Pb}$ ages. Rhyolite geochemistry indicates a mix of tholeiitic to calc-alkaline, ranging from FI, FII, and FIII rhyolites-according with the nomenclature of Lesher [14] — for the NVC $[9,10]$ and the Beaupré dome shares a similar mix, although dominated by FII (Amex Exploration internal data).

The Beaupré rhyolites host the Perron gold system (Figure 1). Rhyolites were dated at $2722 \pm 3 \mathrm{Ma}$ [15] and more recently at $2725.4 \pm 0.9 \mathrm{Ma}$ [12] with a sample taken from a trench made by Amex Exploration Inc. Aphanitic and essentially aphyric rhyolites define a thick $(>1 \mathrm{~km})$ and relatively homogeneous sequence. Rhyolites at the base are massive with flow bandings but are brecciated at the top, consistent with a south-facing dome interpretation. Rhyolite colors vary from dark green to grayish or even whitish locally. It is dotted with 2-3-mm spots of chlorite or locally garnet. The dark green color reflects a chlorite hydrothermal alteration. Mafic aphanitic dykes and bodies crosscut the rhyolites 
(Figure 1). Most are considered as sills because their trend and dip appear parallel to the strata, whereas some are clearly discordant features.

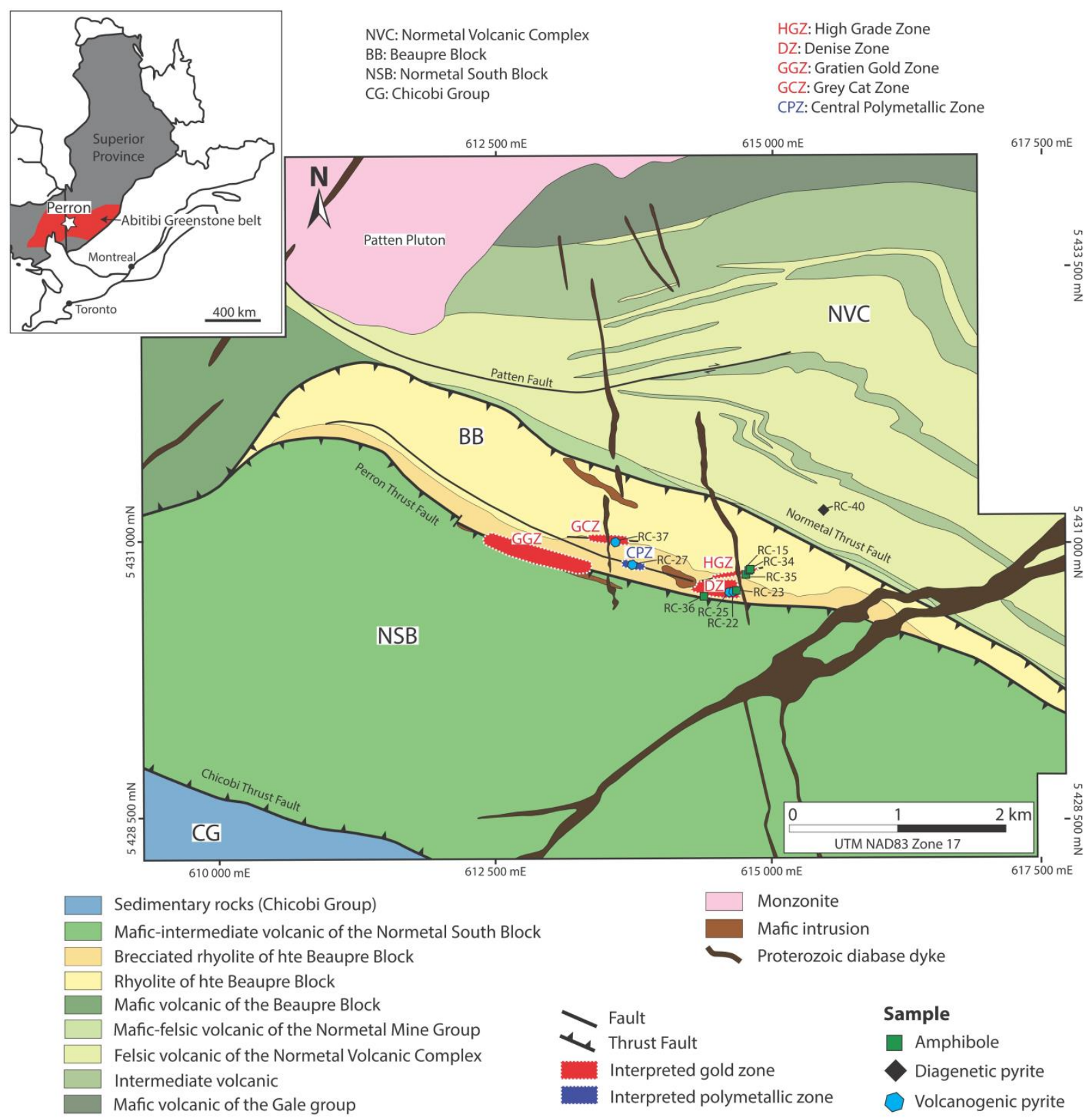

Figure 1. Geological map of the Perron gold project. Note the Beaupré rhyolite dome lying directly above the Western Caldera. Samples used for this study, outside of the HGZ are projected vertically. Star for location of the Perron deposit in the inset. Figure modified from [14] and AMEX Exploration.

The Normétal deformation zone, a regionally extensive NE to E-W steeply north dipping fault, is developed along the Normétal mine volcano-sedimentary horizon, separating the NVC and the Beaupré block (Figure 1). Outside, in the Beaupré block, deformation is very weak in the competent rhyolites. However, incompetent mafic dykes record an $\mathrm{E}-\mathrm{W}$ trending, steeply dipping schistosity. The metamorphism is at greenschist facies regionally. However, in the Beaupré block, amphibolite facies are recorded in the aureole of contact metamorphism [16] from the syn-tectonic Patten pluton (Figure 1) dated at $2687.8 \pm 1.3 \mathrm{Ma}$ [12]. In drill cores, this is manifested by garnet and porphyroblastic randomly oriented amphibole and biotite overprinting the schistosity. 


\section{Gold Mineralizations}

Two types of gold mineralizations are distinguished: (1) sulfide-rich primary volcanogenic; and (2) orogenic quartz-vein type.

\subsection{Primary Sulfide-Rich Gold Mineralization}

The Central Polymetallic Zone (Figure 1) is a typical example of volcanogenic goldbearing mineralization. The zone is devoid of quartz veining but rich in sulfide occurring as stringer of chalcopyrite, sphalerite, pyrite, pyrrhotite (Figure 2A), and locally galena and transposed along the schistosity (Figure 2B,C). Disseminated sulfides also occur within brecciated rhyolite. Sericite and chlorite define the hydrothermal alteration envelope (Figure 2A-C). Silver values are typically $\sim 10$ times higher than gold (Amex internal data; Figure $2 \mathrm{~A}-\mathrm{C}$ ). Higher gold grades are related to higher sulfide contents and are correlative either with zinc or copper values. This zone is interpreted as a discordant linear volcanogenic hydrothermal feeder.

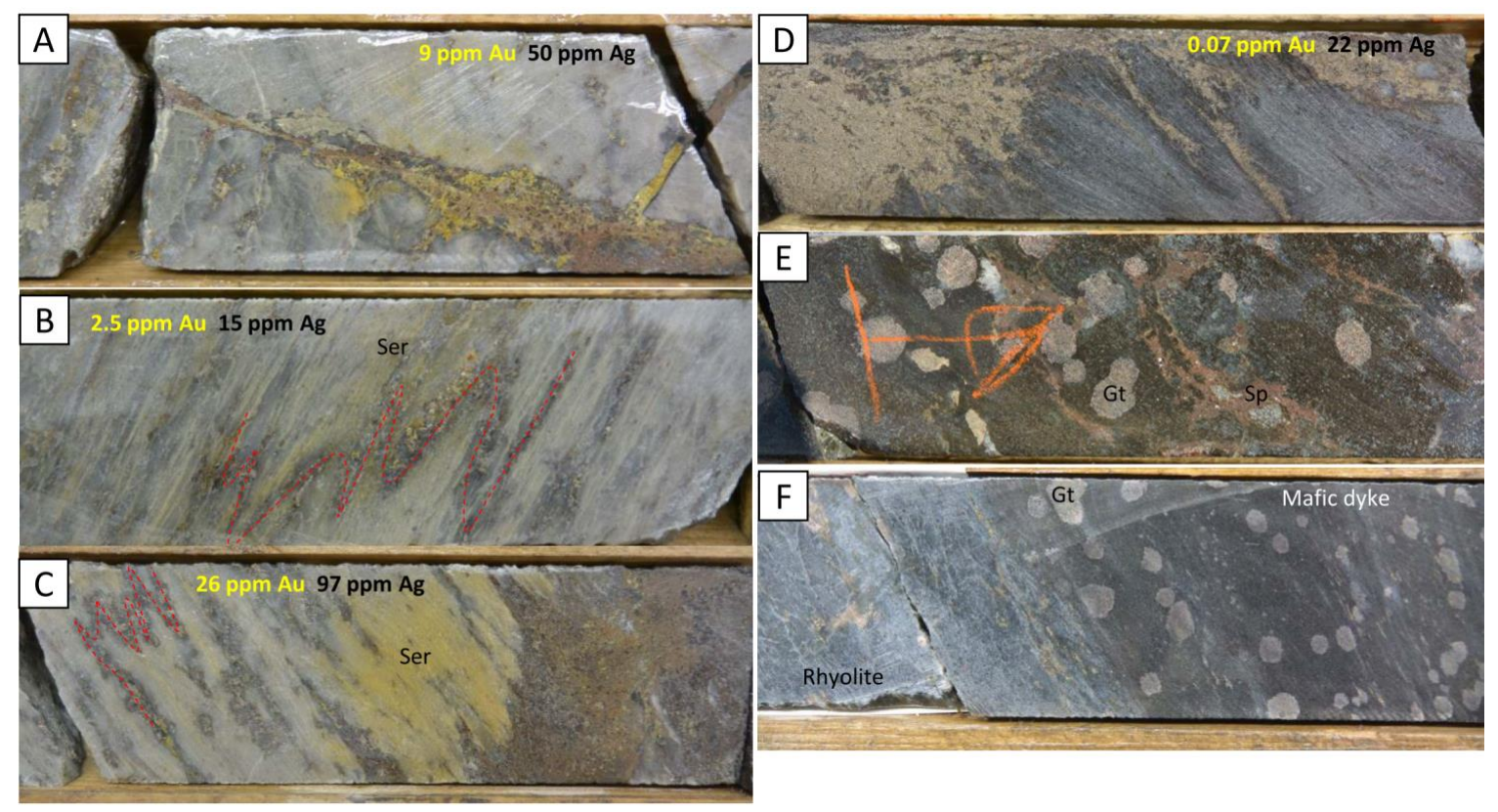

Figure 2. Photographs of the volcanogenic gold mineralization and associated hydrothermal alteration from half-cut NQ drill core (diameter of $4.76 \mathrm{~cm}$ ). (A) Sulfide stringers (chalcopyrite, sphalerite, and pyrite) cutting massive rhyolite in the Central Polymetallic Zone, drill hole PE-2013-03 at 411.7 m. (B) Brecciated rhyolite cuts by stringers of chlorite, sphalerite, and pyrite transposed parallel to the schistosity (red dashed line). The deformation is expressed by the alignment of the sericite (Ser). Central Polymetallic Zone, drill hole PE-2013-03 at $389 \mathrm{~m}$ (sample RC-25). (C) Similar relationships to B with higher gold grade, drill hole PE-2013-03 at $410.7 \mathrm{~m}$ (sample RC-29). (D) Zone of semi-massive and stringer sulfides (sphalerite and pyrite) in an altered mafic dyke, drill hole PE-19-37Ext at $573.25 \mathrm{~m}$ in the Denise zone (sample RC-25). (E) Volcanogenic gold mineralization in an altered mafic dyke with sphalerite stringers (Sp) and large garnets (Gt) superimposed on chlorites and biotites, Denise zone, hole PE-2019-37Ext at $563 \mathrm{~m}$. (F) Porphyroblastic garnets in a mafic dyke in contact with a rhyolite, drill hole PE-2013-03 at $416 \mathrm{~m}$.

Similar occurrences of primary mineralizations were encountered in numerous drill holes at the project scale. For example, gold-bearing zones of sphalerite and pyrite stringers are also developed in the brecciated rhyolite host of the Gray Cat zone (Figure 1) and within mafic dykes of the Denise zone (Figures 1 and 2D). The mafic unit at the top of the rhyolites also contains evidence of hydrothermal alteration and volcanogenic mineralization. The presence of large garnets (Figure 2E,F) in association with auriferous zones dominated by sphalerite stringers and pyrite supports this interpretation. These mafic dykes could also constitute hydrothermal conduits cutting the rhyolitic dome. 


\subsection{Orogenic Quartz-Vein Type}

The Perron project comprises four different vein-type gold-bearing zones (high-grade zone (HGZ), Denise, Gratien, and Grey Cat) along an E-trending 3.2-km-long corridor (Figure 1). The focus of this study is limited to the HGZ, which is the richest gold zone. This steeply north-dipping zone (Figure 3) is traced by drilling over $350 \mathrm{~m}$ laterally, from near-surface to $>1.2 \mathrm{~km}$ vertically along a $75^{\circ}$ eastern plunge with an average of $\sim 7 \mathrm{~m}$ of width (core length) and a true thickness of 3 to $4 \mathrm{~m}$. From the longitudinal view, the gold mineralization is very continuous, with a central high-grade core with metal factor $>100$ (gold grade in ppm * thickness in meter) bordered by lower grade gold mineralization (Figure 3).

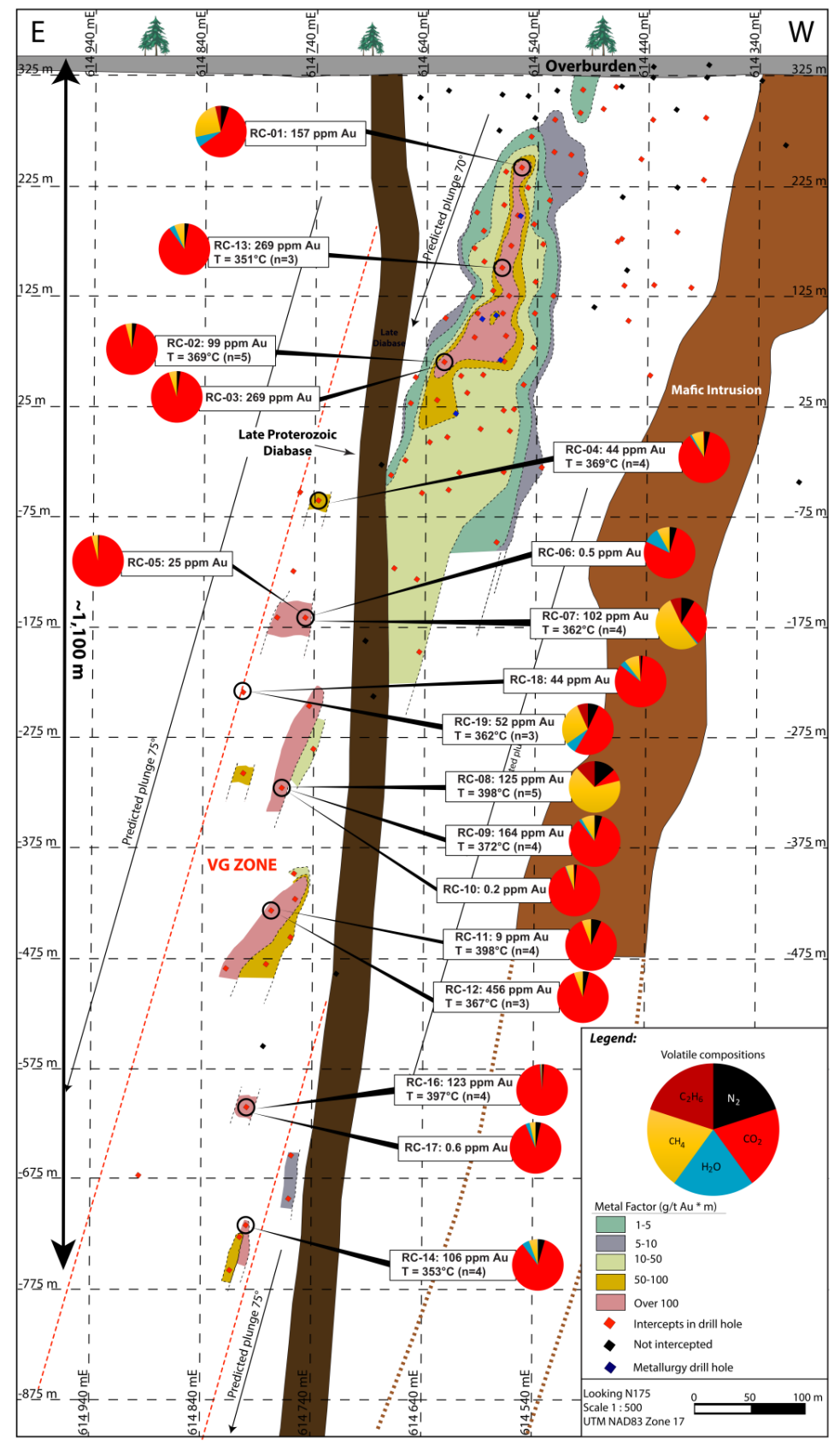

Figure 3. Longitudinal section of the HGZ showing the high-grade gold distribution, the steeply eastplunge of the ore shoot, and the sample locations. Gold assays from AMEX Exploration, sphalerite temperature median value with the number of grains analyzed $(n=\mathrm{X})$, and volatile compositions are plotted (see text). Figure modified from AMEX Exploration. 
The HGZ corresponds to massive, whitish to greyish quartz veins with traces of iron carbonates, green chlorite, and tourmaline. Visible gold grains occur, in order of predominance (Figure 4A): (1) associated with sphalerite; (2) along chlorite ribbons and flakes; and (3) freely in quartz. Brown sphalerite, reaching $>5 \%$ locally is ubiquitous in the veins (Figure $4 \mathrm{~A}, \mathrm{~B})$ as well as pyrite $(<2 \%$ : Figure $4 \mathrm{~A}, \mathrm{C})$. Sphalerite texture varies from massive aggregate $(<3 \mathrm{~cm})$ to trails of disseminated grains (Figure $4 \mathrm{~B})$ whereas pyrite commonly occurs as millimetric parallel bands (Figure 4C). Distorted ribbons of chloritized and pyritized host rocks are common near the contacts (Figure 4D). The HGZ is developed at the interface of a deformed mafic dyke, which acted as a planar anisotropy for shearing. Veins occur either along one side or the other or along both sides of the dyke and occasionally within the dyke, especially at depth. A fundamental observation is that the quartz veins were formed by dilatation within the shear zone (Figure 4E). Genetically, they are not shear veins [17]. Their origin in extension is manifested by ribbons of host rocks indicating sequential crack-seal openings of already schistose mafic dyke and rhyolite, without evidence of displacement along the ribbons (Figure 4D,E). Hydrothermal alteration is very weak, even within mafic dykes. It is manifested by chloritization of mafic dykes with the local presence of leucoxene and weak sericite alteration of rhyolites. Other gold-bearing zones have similar characteristics.
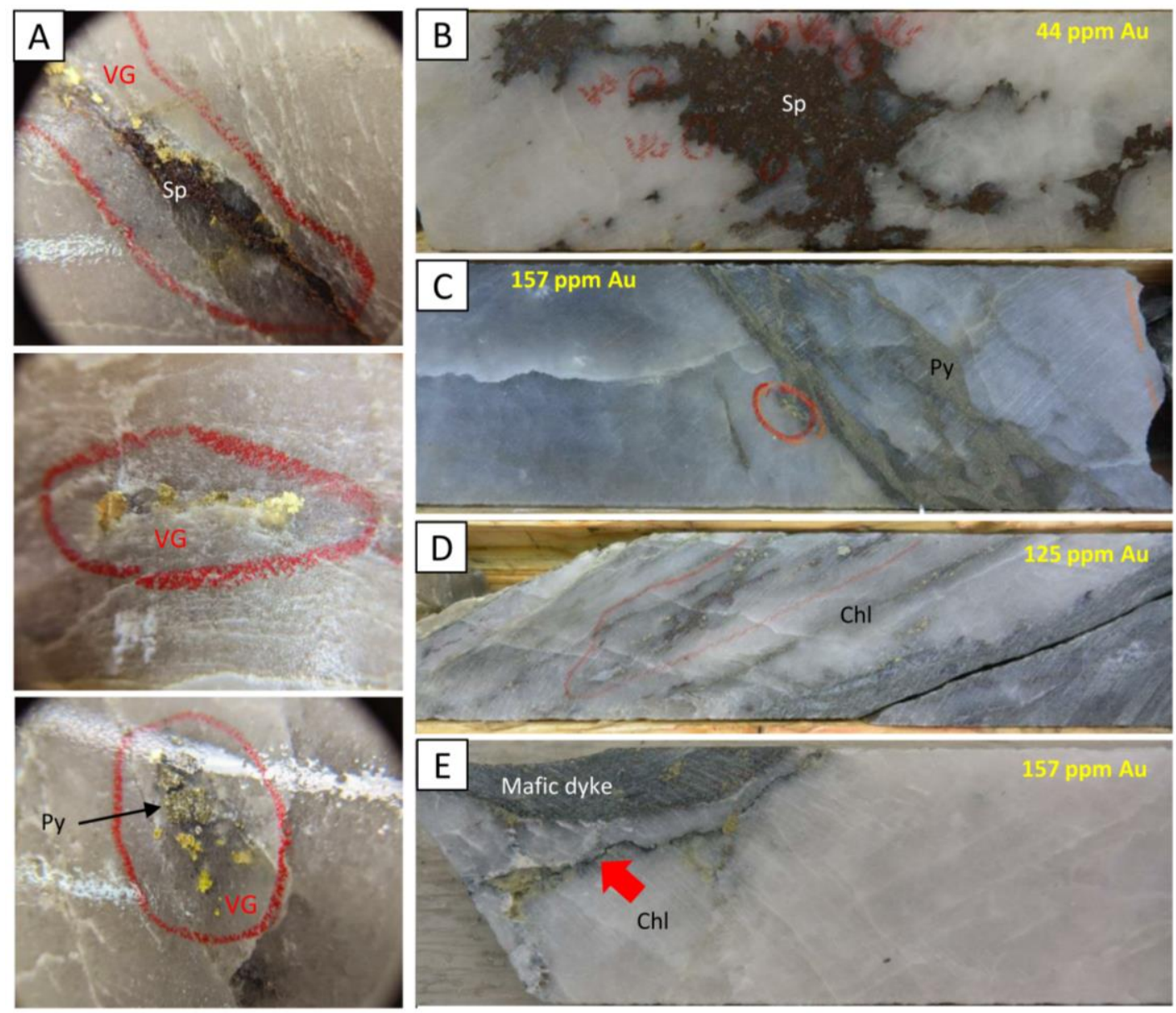

Figure 4. Photographs of the HGZ vein-type gold mineralization from half-cut NQ drill core (diameter of $4.76 \mathrm{~cm}$ ). (A) Examples of visible free gold (VG: visible gold) in drill hole PE-20-192. Source AMEX Exploration Inc. (B) Brown sphalerite aggregate (Sp) with numerous visible gold grains (red circle), drill hole PE-19-132 at $455.9 \mathrm{~m}$ (sample RC04). (C) Pyrite (Py) forming parallel bands with visible gold (red circle), drill hole PE-19-31 at $136.9 \mathrm{~m}$ (sample RC-01). (D) Parallel ribbons of chlorite (Chl), with disseminated pyrite and sphalerite and visible gold, drill hole PE-20-165 at $709.3 \mathrm{~m}$ (sample RC-08). (E) Distorted ribbons of chloritized and pyritized host rocks teared off from a mafic dyke (red arrow), drill hole PE-19-31 at $136.0 \mathrm{~m}$. 


\section{Material and Methods}

Sampling from drill cores is as follows: (1) 18 samples in 10 drill holes from the HGZ to cover its vertical distribution, with a range of high- $(456.28 \mathrm{ppm})$ to low-grade $(0.19 \mathrm{ppm})$ gold values (Figure 3); (2) 7 samples from the primary volcanogenic gold mineralization to cover the various styles and sulfide assemblages, with gold ranging from 0.035 to $9.27 \mathrm{ppm}$ $\mathrm{Au}$ (Figure 1); and (3) 5 samples of mafic rocks with porphyroblastic amphiboles (Figure 1). A 30- $\mu \mathrm{m}$ polished thin section was fabricated for all samples for petrographic observations and in-situ analytical purposes. For the HGZ, samples were systematically taken from the drill core portion with the highest content of visible gold grains.

Fluid inclusions of samples from the orogenic quartz veins were analyzed by solidprobe mass spectrometry following the method of Gaboury et al. [18] at the Laboratoire de Métallogénie Expérimentale et Quantitative (LAMEQ), Université du Québec à Chicoutimi (UQAC), Chicoutimi, Canada. Quartz samples of $\sim 10 \mathrm{mg}$ were analyzed for monitoring 10 volatiles $\left(\mathrm{H}_{2} \mathrm{O}, \mathrm{CO}_{2}, \mathrm{~N}_{2}, \mathrm{C}_{2} \mathrm{H}_{6}, \mathrm{He}, \mathrm{Ar}, \mathrm{CH}_{4}, \mathrm{SO}_{2}, \mathrm{H}_{2} \mathrm{~S}\right.$, and $\left.\mathrm{H}_{2}\right)$ using a Stanford Research System RGA100 residual gas analyzer (Sunnyvale, CA, USA) with an electron multiplier.

Trace element concentrations in pyrite and sphalerite were measured by laser ablation inductively coupled plasma mass spectrometry (LA-ICP-MS) on 30- $\mu \mathrm{m}$-thin polished thin sections of orogenetic quartz veins and from volcanogenic sulfide-rich samples. The analyses were performed at LabMaTer (UQAC), using an Excimer $193 \mathrm{~nm}$ Resonetics Resolution M-50 laser ablation system coupled with an Agilent $7700 \times$ mass spectrometer. Analyses were performed using lines according to the procedures of Genna and Gaboury [19] and Augustin and Gaboury [20]. Iron was used as an internal standard using stoichiometric values. Sulfides analyses were calibrated using MASS-1 and GSE and data quality was verified using UQAC-FeS1 and UQAC-FeS5 (Supplementary Materials, Table S1).

The sphalerite GGIMFis geothermometer [21] was used to determine the mineralization temperature of the HGZ using the chemical composition of sphalerite from LA-ICP-MS analyses. For data reduction, the stoichiometric sulfur concentration was used as an internal standard to calculate the Fe content of sphalerite.

The chemical compositions of the porphyroblastic amphiboles in mafic rocks were analyzed in carbon-coated thin sections using a Cameca SX-100 microprobe at Université Laval (Quebec City, QC, Canada), using a $15 \mathrm{keV}$ accelerating potential, a $20 \mathrm{nA}$ intensity, and a 5-micron-diameter beam. Amphibole formulas and geothermometric data (calibrated on experimental data) were calculated using the Excel spreadsheet of Locock [22] and Zenk and Schulz [23], respectively.

\section{Result}

\subsection{Sulfide Mineralogy and Gold Habit}

Visible gold occurs mostly as yellowish irregular grains $<5 \mathrm{~mm}$ in quartz veins with a common spatial association with sphalerite, either in contact or not (Figure 5). Visible gold locally occurs in quartz (Figure 5A,D,E) and exceptionally as inclusions in pyrite (Figure 5F). In quartz, gold occurs mostly along fractures (Figure 5E). Two morphologic types of pyrite are distinguished: (1) subhedral to locally anhedral pyrite (Py1) with porous cores (Figure 5) commonly distributed as bands and aggregates (Figure 4C); and (2) well-defined pentagonal dodecahedron crystals (Py2) spatially associated with sphalerite (Figure 5B). Sphalerite occurs as void filling in quartz veins (Figure 5B,D) and along fractures. Sphalerite also fills fractures within aggregates of subhedral pyrite Py1 (Figure 5C). These relationships indicate that sphalerite and gold are a later filling event regarding quartz and pyrite Py1. Locally, pyrrhotite is also associated with sphalerite (Figure 5D). 

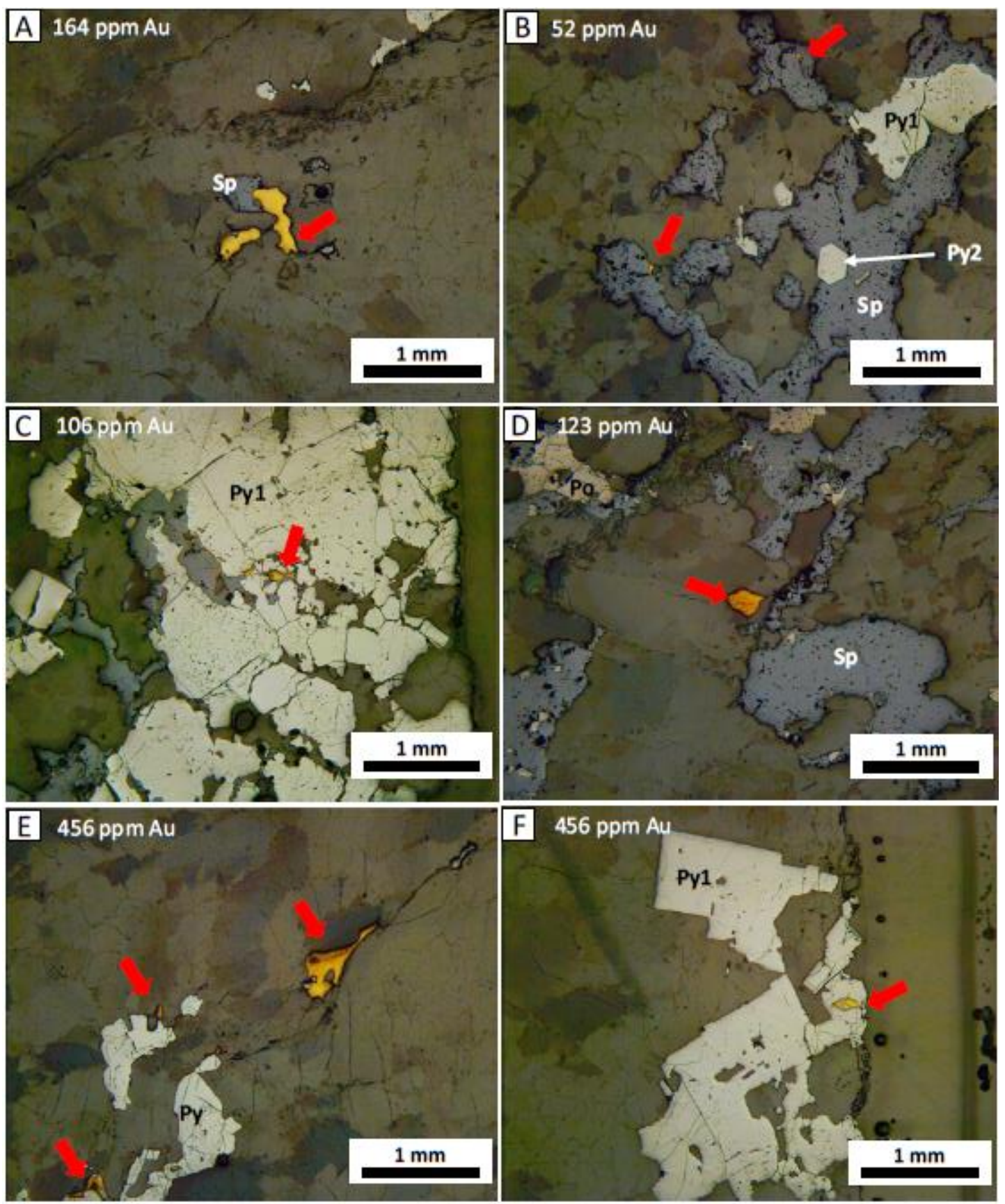

Figure 5. Photomicrographs of the sulfide mineralogy and texture, and visible gold habit in the HGZ quartz veins. Gold assays are given in ppm for reference. (A) Gold (red arrow) in quartz in contact with sphalerite (Sp), sample RC-09. (B) Gold in association with sphalerite, note the difference between pyrite Py1 (subhedral) and Py2 (pentagonal dodecahedron) in sphalerite, sample RC-19. (C) Gold associated with sphalerite cutting across pyrite Py1, sample RC-14. (D) Gold in quartz with a spatial association to sphalerite, note the pyrrhotite (Po) associated sphalerite, sample RC-16. (E) Gold in quartz occurring along a fracture with gold in contact with pyrite, sample RC-12. (F) Gold as inclusion in pyrite Py1, sample RC-12.

\subsection{Fluid Inclusion Petrography}

Petrographic observations were performed on the 18 quartz samples from the HGZ quartz veins to: (1) validate if fluid inclusions can account for the released gas; (2) establishing specific fluid inclusion types; (3) looking for the occurrence of daughter mineral, such as halite; and (4) establishing the genetic link between fluid inclusions and visible gold. 
Phase assemblages were established at room temperature $\left(22^{\circ} \mathrm{C}\right)$. Quartz samples are characterized by assemblages of fluid inclusions, mostly distributed as clusters and trails of secondary origin as expected for vein-type gold deposits (e.g., [24]). Fluid inclusions are very diversified in shape and color, ranging from ovoidal to flame-shaped, transparent to dark (Figure 6). Four types are distinguished: (1) ovoid, 1 phase liquid or gaseous; (2) ovoid, 2 phases liquid with a small bubble of darker gas; (3) ovoid, 1 phase dark gaseous; and (4) flame-shaped 1 phase dark gaseous (Figure 6). As an empirical relationship, samples with very low gold grades are dominated by type 1 fluid inclusion, type 3 and 4 are more abundant in gold-rich samples whereas type 2 is very rare. The scarcity of the type 2 fluid inclusions is also noteworthy. Typically, water-rich, 2 phases are the most common fluid inclusions in orogenic gold deposits as they are formed by aqueous-carbonic fluids [25-31].

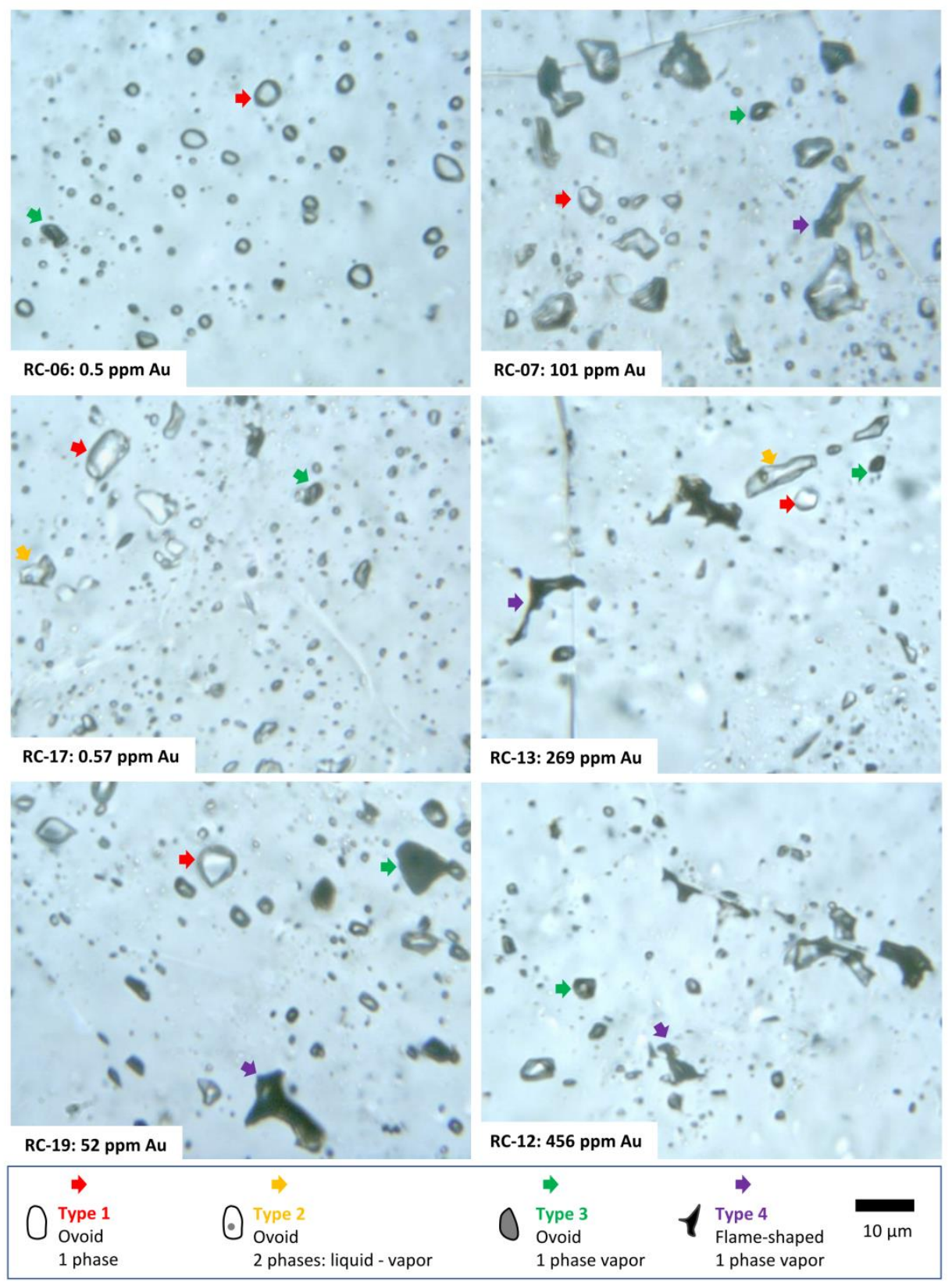

Figure 6. Photomicrographs showing the petrographic characteristics of fluid inclusions. Selected samples are ordered according to gold grade as indicated in ppm. Type 1 appears more abundant in low gold grade, where type 3 and 4 are dominant in gold-rich samples. Type 2 was observed only in 2 samples. The Zerene Stacker software was used to enhance the focus. 
Petrographic criteria are the only method to distinguish fluid inclusion generations [25] and their genetic link with mineralization. Visible gold is spatially related to type 3 fluid inclusions where trails of secondary fluid inclusions are aligned toward gold (Figure 7). This textural evidence supports the interpretation that secondary fluid inclusions are representative of the gold mineralizing event.

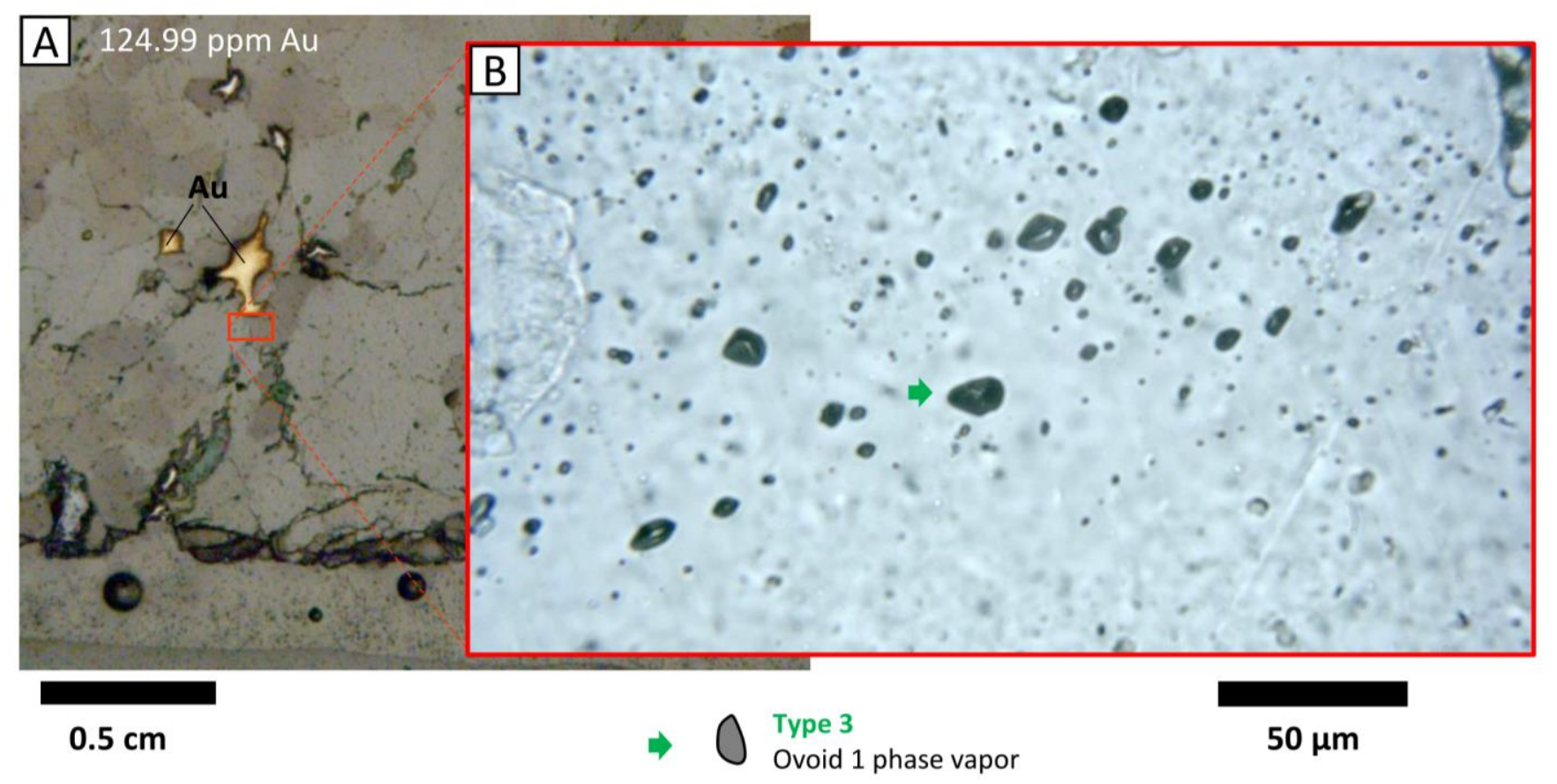

Figure 7. Link between fluid inclusions and visible gold. (A) Photomicrograph of visible gold grains hosted in quartz: sample RC-08 with 124.99 ppm Au. The red rectangle is the location of Figure 7B. (B) Photomicrograph of fluid inclusions of type 3 aligned toward the visible gold grains, supporting the genetic link between the gaseous fluid inclusions and gold mineralization.

\subsection{Volatile Composition of Fluids in the HGZ}

Volatile compositions of fluid inclusions were obtained from 18 samples to decipher any specific composition related to higher gold grades and vertical distribution. Volatile composition results are presented as a graph of mole \% calculated over a temperature range of 100 to $500{ }^{\circ} \mathrm{C}$ to include all the analytical signal (Figure 8A, Supplementary Materials, Table S2). An example of the mass spectrometric time-resolved analytical signal is presented in Figure $8 \mathrm{~B}$. All samples from the HGZ contain $\mathrm{CO}_{2}$ (7.5-97.4 mole \%), $\mathrm{CH}_{4}\left(0.6-66.6\right.$ mole \%), and $\mathrm{N}_{2}(0.8-13.42$ mole \%). Ethane is a common constituent $(<11.9$ mole \%). Water is only a minor constituent of the fluids, with values $<9.8$ mole $\%$, and not detected in 6 samples, supporting the petrographic observations. The fluids also contain $\mathrm{Ar}$ (up to 0.6 mole $\%$ ), $\mathrm{H}_{2} \mathrm{~S}$ (up to $0.12 \mathrm{~mole} \%$ ), and $\mathrm{He}$ (up to 0.06 mole \%). Hydrogen and $\mathrm{SO}_{2}$ were not detected.

No direct correlation can be established between gold grades and specific components of the fluids (Figure 8A). Therefore, the empirical relationships between fluid inclusion types and gold grades are not supported by the analytical results. In addition, no vertical zoning of the fluid composition can be defined along the HGZ plunge (Figure 3). Rather, fluid composition at the scale of the HGZ should be considered relatively homogeneous in terms of gaseous components, although some variations in mole \% are inherent from the summation to $100 \%$.

On a comparative basis, mineralizing fluids are unique by their low water but significant $\mathrm{CO}_{2}, \mathrm{CH}_{4}, \mathrm{C}_{2} \mathrm{H}_{6}$, and He contents. Typically, mineralizing fluids for orogenic gold deposits are dominated by water with carbon dioxide (e.g., [25-31]). Implications of such particular mineralizing fluids are discussed below. 


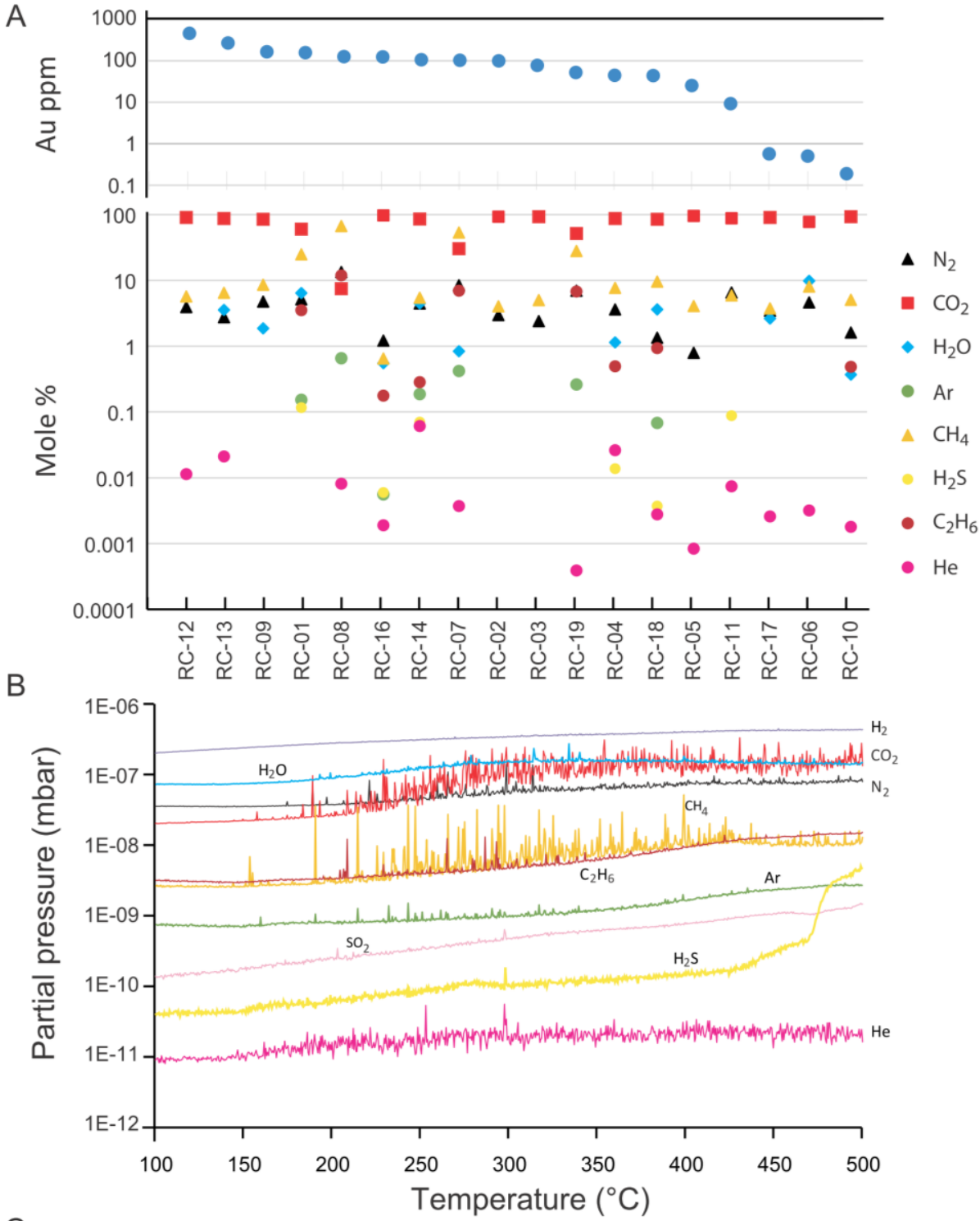

C

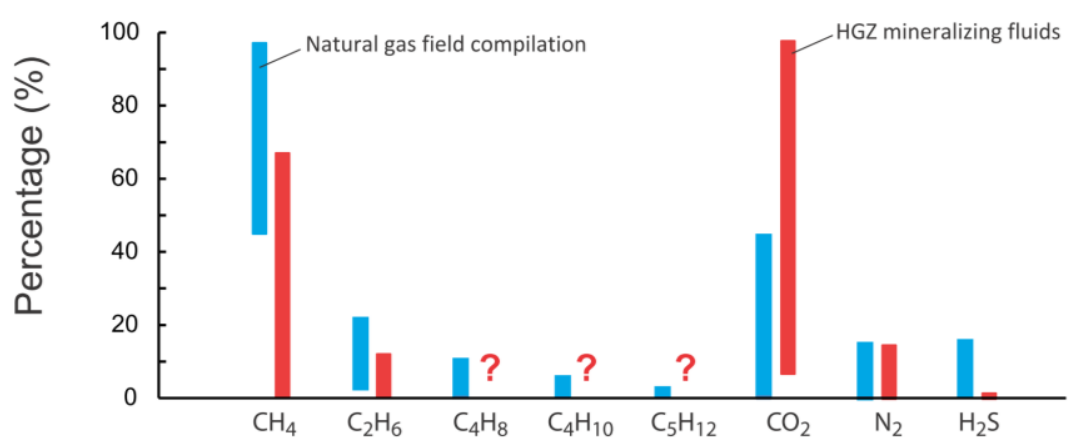

Figure 8. Results of the fluid inclusion analysis by solid probe mass spectrometry. (A) Logarithmic graph of mole \% of volatile components of quartz samples from the HGZ, ordered according to the gold grade of the samples. (B) Example of a mass spectrometric time-resolved signal generated over the temperature range of $100-500{ }^{\circ} \mathrm{C}$ for the 10 volatiles analyzed for sample RC-18. Fluid inclusion decrepitations are manifested by the sawtooth signal above the background. (C) Comparison between the ranges of composition for fossil gas [32] versus the mineralizing fluids documented for the HGZ (this study). 


\subsection{Pyrite Composition}

LA-ICP-MS trace element analyses of pyrite grains (Supplementary Materials, Table S3) were generated for: (1) comparing the HGZ with the large database generated by the CONSOREM from various types of gold deposits in the Abitibi belt; (2) considering particular composition for providing input about genetic processes; and (3) testing potential gold sources for the HGZ.

Results are presented in multielement diagrams (Figure 9) normalized to Archean sedimentary pyrite (ASP: internal compilation from CONSOREM), where elements are sequenced in decreasing order of abundance for orogenic gold deposits [33]. For the HGZ (Figure 9A), the pyrite composition is very homogeneous for all the analyzed pyrite, regardless of their shape (Py1 vs. Py2). There is no significant variation of the composition vertically, nor in association with the gold grade. On a comparative basis, pyrites of the HGZ plot along the field defined by orogenic gold deposits of the Abitibi belt formed by metamorphic fluids (Figure 9B). Magmatic contribution of fluids and gold are typically manifested by higher concentrations of $\mathrm{Ag}, \mathrm{As}, \mathrm{Bi}, \mathrm{Mo}, \mathrm{Te}, \mathrm{Tl}$, and $\mathrm{W}$, as illustrated in Figure $9 \mathrm{~B}$. Hence, a significant contribution of gold from a magmatic source can be ruled out for the HGZ.

Pyrites from volcanogenic gold mineralization are clearly different from the HGZ (Figure 9C), by having enrichment of In, Zn, and Cd up to 1000 times to normalizing values, and depletion of As up to 1000 times. Copper is also significantly depleted with comparable values to HGZ pyrites. Overall, the signature is not as homogenous as for the HGZ (Figure 9C), an expected feature for volcanogenic-related mineralization (e.g., [19,34]).

Pyrites from a graphitic shale horizon, stratigraphically below the Normétal mine horizon (Figure 1), were also analyzed as a potential source of gold. Two types of pyrite occur: nodular pyrite and euhedral pyrite, both having distinctive trace element signatures (Figure 9D). The nodular pyrites are gold-bearing, with a range of 1.51 to $2.49 \mathrm{ppm}$, whereas the euhedral pyrites are barren (Supplementary Materials, Table S3). The nodular pyrites have an overall signature closer to the normative values as expected, except for depletion of $\mathrm{Cu}$ and enrichment of Tl. The euhedral pyrites have a very similar pattern with the HGZ pyrites, except for Te and Bi depletions. The implications of the various pyrite compositions are discussed below.

\subsection{Sphalerite GGIMFis Geothermometer}

Sphalerite chemistry is strongly controlled with fluid temperatures. Frenzel et al. [21] established an empirical relationship between the homogenization temperature of fluid inclusions in sphalerite, with concentrations of Ge, Ga, Mn, and In in ppm and Fe in wt $\%$ as follows:

$$
\begin{gathered}
P C 1 *=\ln \left(\frac{C_{G a}^{0.22} \cdot C_{G e}^{0.22}}{C_{F e}^{0.37} \cdot C_{M n}^{0.20} \cdot C_{I n}^{0.11}}\right) \\
\mathrm{T}\left({ }^{\circ} \mathrm{C}\right)=-(54.4 \pm 7.3) P C 1 *+(208 \pm 10)
\end{gathered}
$$

Using these equations, referred to as the GGIMFis geothermometer [21], the temperature of sphalerite formation can be calculated. In total, 43 sphalerite grains from 10 samples distributed vertically in the HGZ were used (Figures 3 and 10), Supplementary Materials, Table S4). For each sample, between three and five grains were analyzed. Calculated temperatures range from 343 to $426^{\circ} \mathrm{C}$ with a median value of $370 \pm 31{ }^{\circ} \mathrm{C}$ (Figure 10). Along the $\sim 1200 \mathrm{~m}$ sampled, there is no significant vertical variation of temperature. This is consistent with the constant mineralogy, gold grade of the HGZ, and color of sphalerite. Since sphalerite is intimately related to gold (Figures 4 and 5), it is considered that $370 \pm 31^{\circ} \mathrm{C}$ is the temperature of the gold mineralization for the HGZ. By comparison, this temperature is higher than the median $254{ }^{\circ} \mathrm{C}$ value (range of $50-462{ }^{\circ} \mathrm{C}$ ), compiled from homogenization temperatures of fluid inclusions for Meso and Neo-Archean gold deposits worldwide [31]. 

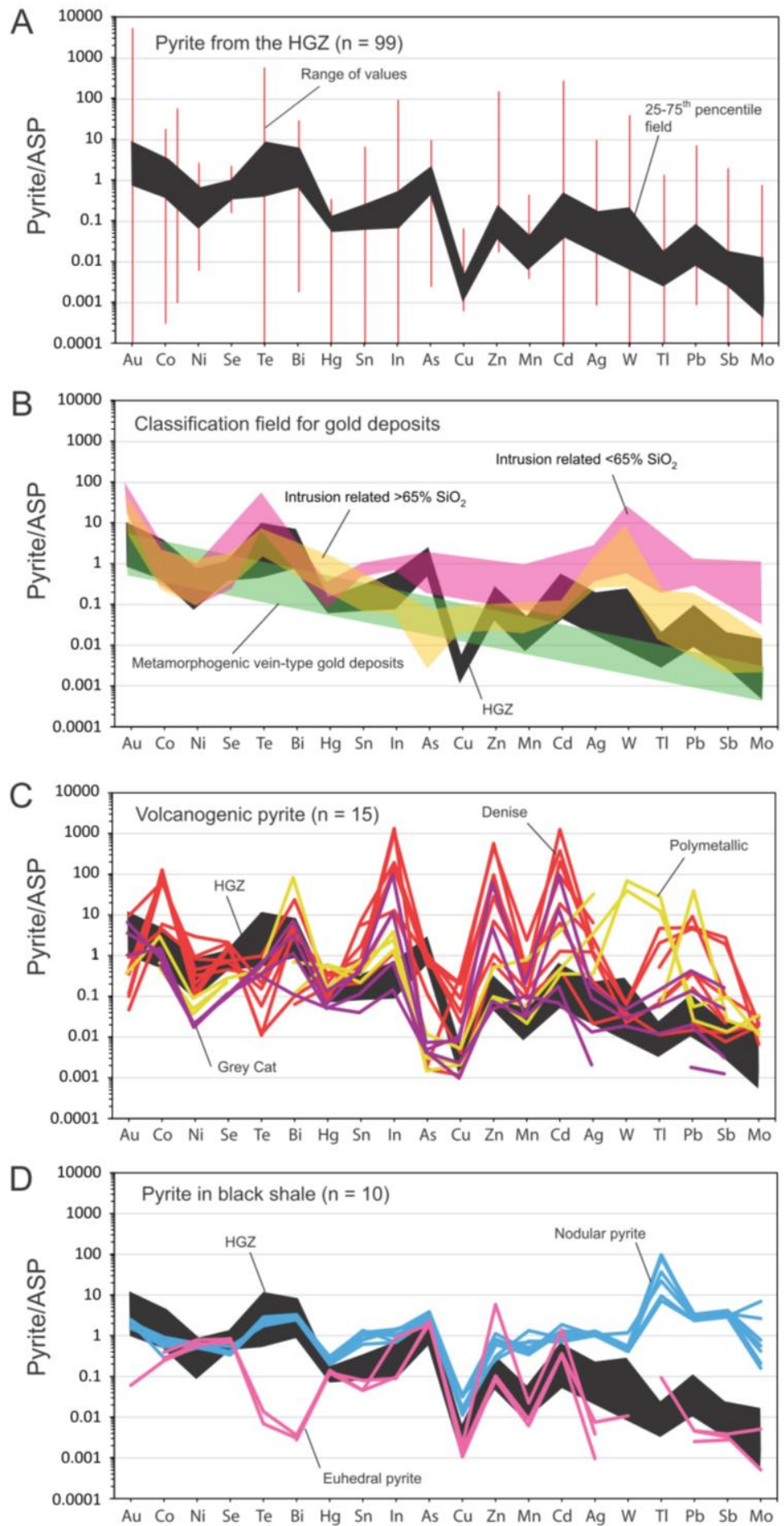

Figure 9. Multi-element diagrams from Genna et al. [33] for pyrites analyzed by LA-ICP-MS and normalized to ASP (Archean Sedimentary Pyrite). (A) Result for pyrites from the HGZ. The range of values is given by the red lines whereas values between the 25 th and 75 th percentiles are delimited by the black envelope. Data considered relatively homogeneous as values within the 25-75th percentile field are not spreading more than one order of magnitude. (B) Classification patterns for orogenic gold deposits of the Abitibi belt, based on $>1000$ pyrite analyses from 18 well-studied gold deposits [33]. The HGZ data, illustrated by the 25-75th percentile envelope, plot closer to the metamorphogenic field. (C) Volcanogenic pyrite data from 3 different mineralized zones, showing very different patterns in comparison to the HGZ pyrites. (D) Pyrites from a graphitic black shale horizon (Figure 1), showing similarity with the HGZ pyrites. 


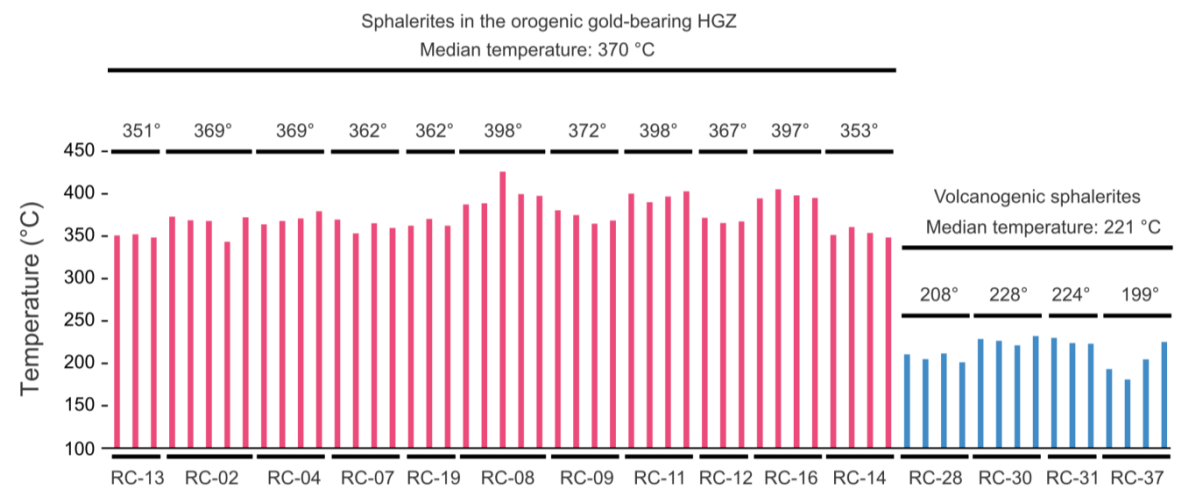

Figure 10. Graph of temperatures calculated with the GGIMFis geothermometer [21] for the HGZ and volcanogenic sphalerite grains. Samples from the HGZ are ordered according to their depth (Figure 3). Given temperatures are median values for each sample.

For volcanogenic sphalerites, four samples from the Gratien, Grey Cat, and Polymetallic zones were used. Temperatures from the 15 analyzed grains are homogenous, ranging from 181 to $232{ }^{\circ} \mathrm{C}$ with a median value of $221 \pm 12{ }^{\circ} \mathrm{C}$ (Figure 10). These values are within the expected range for Archean volcanogenic zinc-bearing mineralizations (e.g., [19]).

\subsection{Amphibole Thermobarometry}

Calcic amphibole composition can be used for establishing the temperature and pressure of the peak metamorphism recorded by mafic rocks (e.g., [35]). Porphyroblastic amphiboles are prismatic to needle-shaped crystals, locally poikiloblastic, with random orientations and dimensions less than $2 \mathrm{~cm}$ (Figure 11). Some amphibolite crystals overprint the biotite schistosity (Figure 11A,B) whereas others are warped by biotite schistosity (Figure 11C), clearly demonstrating their late metamorphic development.
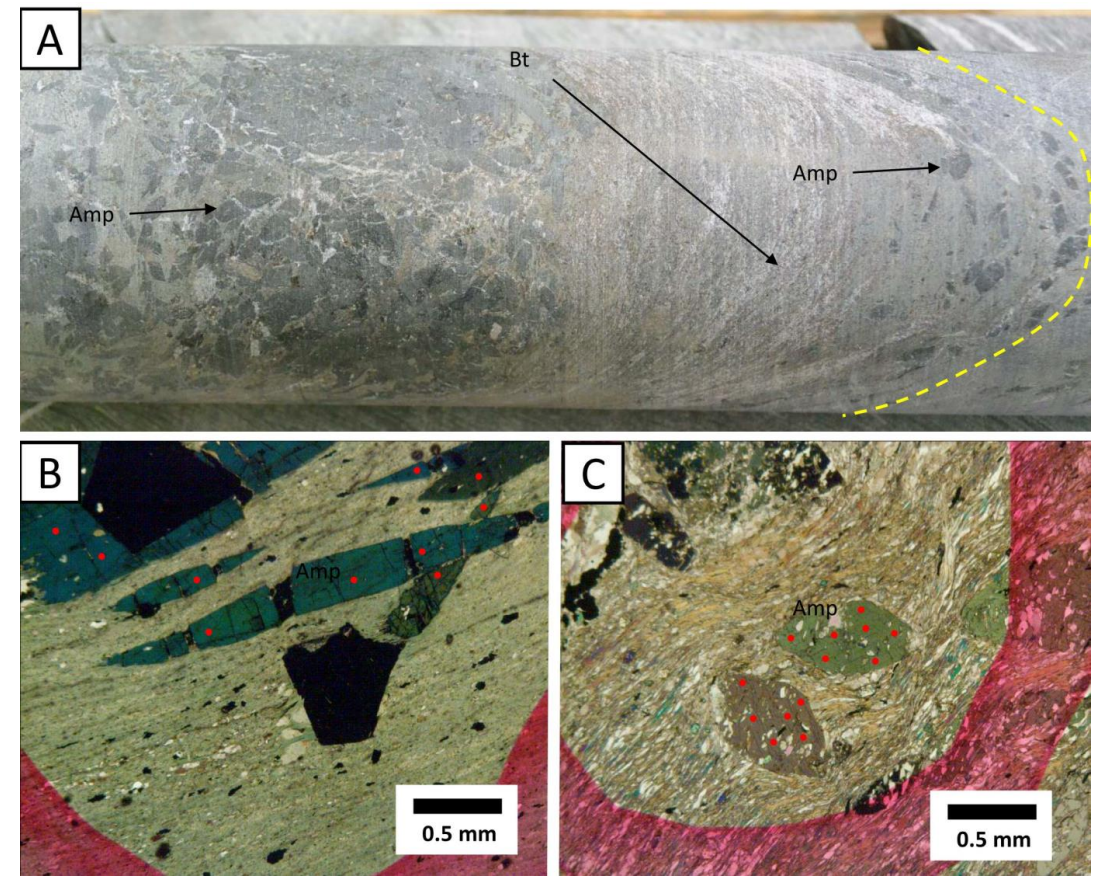

Figure 11. Amphibole textural relationships. (A) Photograph of a drill core where prismatic amphiboles (Amp) overprint the schistosity (dashed yellow line) defined by aligned biotites (Bt) in mafic rocks. (B) Photomicrograph (polarized light) showing needle-shaped amphiboles overprinting the schistosity (chlorite), sample RC-22. (C) Photomicrograph (polarized light) showing prismaticshaped amphiboles with warped biotite-bearing schistosity, sample RC-35. The red dots in (B) and (C) are microprobe spot analyses. 
A total of 111 analyses were performed on amphibole crystals (Supplementary Materials, Table S5). Results from the same sample are very homogeneous (Figure 12A). According to the calcic amphibole classification of Hawthorne et al. [36], they are mostly magnesio-hornblende to tschermakite with lesser pargasite (Figure 12A). Calculations of the peak pressure-temperature of the metamorphism were performed using the equations of Zenk and Schulz [23]. Pressure values range from 4.7 to $6.1 \mathrm{kbar}$ with a median of $5.6 \mathrm{kbar}$, whereas temperature reached a median of $599^{\circ} \mathrm{C}$ from values of 545 to $630{ }^{\circ} \mathrm{C}$ (Figure 12B, Supplementary Materials, Table S5). The absolute error is $\pm 1.2 \mathrm{kbar}$ and $\pm 37^{\circ} \mathrm{C}$. These values are compatible with amphibolite conditions, in accord with the mineralogical assemblage of porphyroblastic amphibole, biotite, and garnet resulting from the contact metamorphism.

A

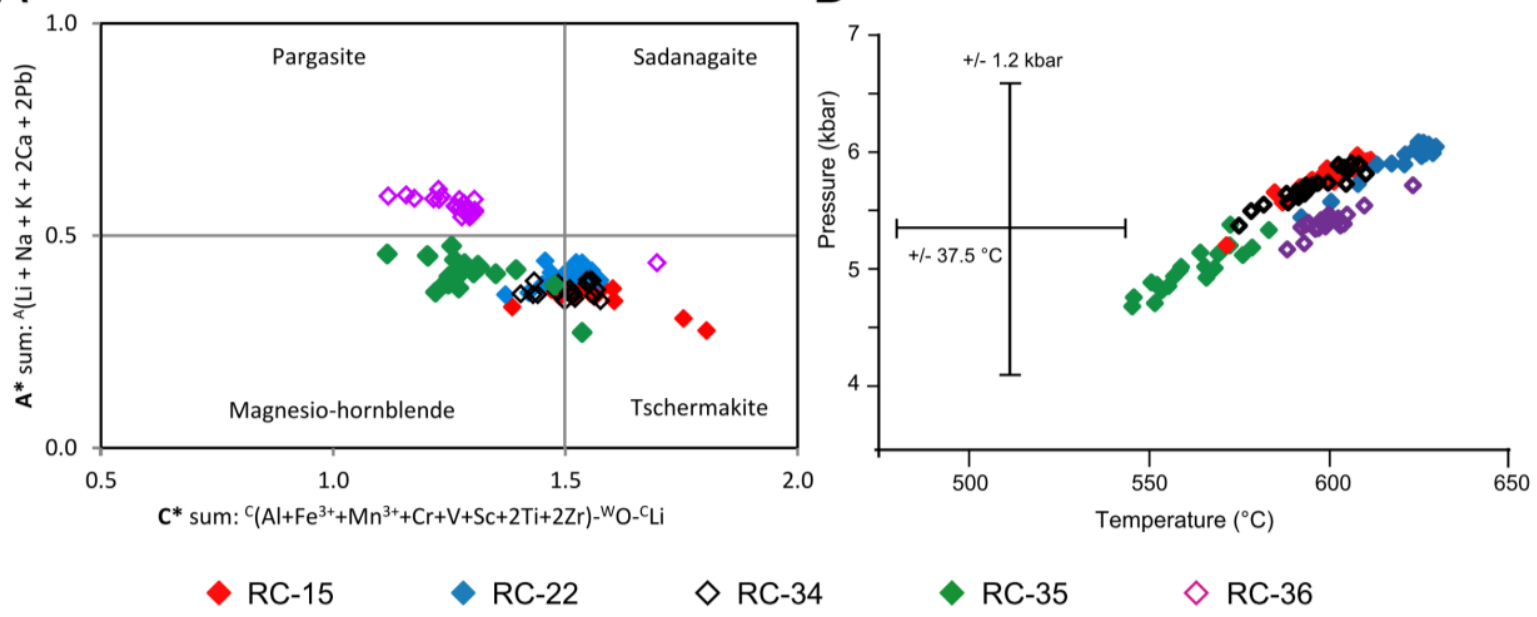

Figure 12. Amphibole compositions and geothermometric data. (A) Plot of the calcic-amphiboles in the classification diagram of Hawthorne et al. [36], where $A^{*}$ and $C^{*}$ refer to the summation of various ions, as stated. (B) Pressuretemperature diagram developed using the method of Zenk and Schulz [23].

\section{Discussion}

\subsection{Tectono-Thermal Evolution}

To test the various hypotheses for gold enrichment, is it fundamental to constrain the tectonic and thermal evolution of the mineralizing system, from primary volcanogenic ore to late gold-rich quartz veins (Figure 13). The tectonic evolution can be bracketed in time by the age of the host Beaupré rhyolite (2725 Ma) and the syn-tectonic Patten pluton (2688 Ma). The thermal evolution is constrained by the amphibole temperature $\left(600^{\circ} \mathrm{C}\right)$ for the peak metamorphism related to the Patten pluton and sphalerite temperature for the late gold $\left(370^{\circ} \mathrm{C}\right)$ and volcanogenic mineralizations $\left(221^{\circ} \mathrm{C}\right)$. Since orogenic gold mineralizations are commonly in thermal equilibrium with their host rocks [37], a cooling of $\sim 230^{\circ} \mathrm{C}$ occurred before the formation of the HGZ (Figure 13). Too many parameters remain undetermined to calculate the conductive cooling rate and thus a timeframe for the late formation of the gold mineralization. Nevertheless, the tectono-thermal evolution indicates a late formation of the HGZ. However, a post-Archean formation appears unlikely as the HGZ is cut by a Proterozoic dyke (Figure 3), a typical feature of all the orogenic gold mineralizations in the Archean Abitibi belt [7].

\subsection{Gold Precipitating Mechanisms and Remobilization}

Quartz vein-type high-grade gold deposits were the focus of recent papers to address why some veins or segments are so rich in gold, considering that gold solubility is generally at ppb levels for aqueous hydrothermal fluids [38-40]. Hastie et al. [41], for Archean deposits in Canada, invoke a remobilization of gold from primary pyrites by coupled dissolution-reprecipitation where gold is remobilized by fluid-mediated means, 
by $\mathrm{Hg}-\mathrm{Te}-$, $\mathrm{Sb}-$, and Bi-rich melts, and/or by local nanoparticle transport during deformation and metamorphism. Voisey et al. [42] proposed a similar model named "Aseismic Refinement" based on the study of the deeper part of the Fosterville gold mine, in the Paleozoic Victoria district, Australia. They argue that once gold is precipitated, mineralization can be significantly enriched through a combination of pressure solution removal of quartz and remobilization-related addition of $\mathrm{Au}$ in specific sites during aseismic periods, hence emphasizing that the entire seismic cycle is important in lode formation. Gaboury and Sanchez Ore [43] proposed an efficient electrochemical gold precipitating mechanism induced by negative and positive pyrites to explain the extensive vertical and lateral high-grade mineralization in the world-class Paleozoic Poderosa-Pataz district.

The proposed enrichment mechanisms of Hastie et al. [41] and Voisey et al. [42] involve localized modifications of primary gold ore, incompatible with the vertically extensive and homogeneous distribution of the high-grade gold values of the HGZ. Furthermore, these enrichments are related to pressure fluctuations of fault-fill veins and thermal metamorphic effect whereas the HGZ was formed by later extension and at a lower temperature than the metamorphic peak. The electrochemical mechanism is more coherent with such a wide-spread spatial high-grade gold distribution, but visible gold is not specifically associated with pyrite. Other factors should be considered to account for the exceptional gold enrichment of the HGZ, such as enhanced fluid solubility for gold and a particular gold endowment for saturating the fluids.

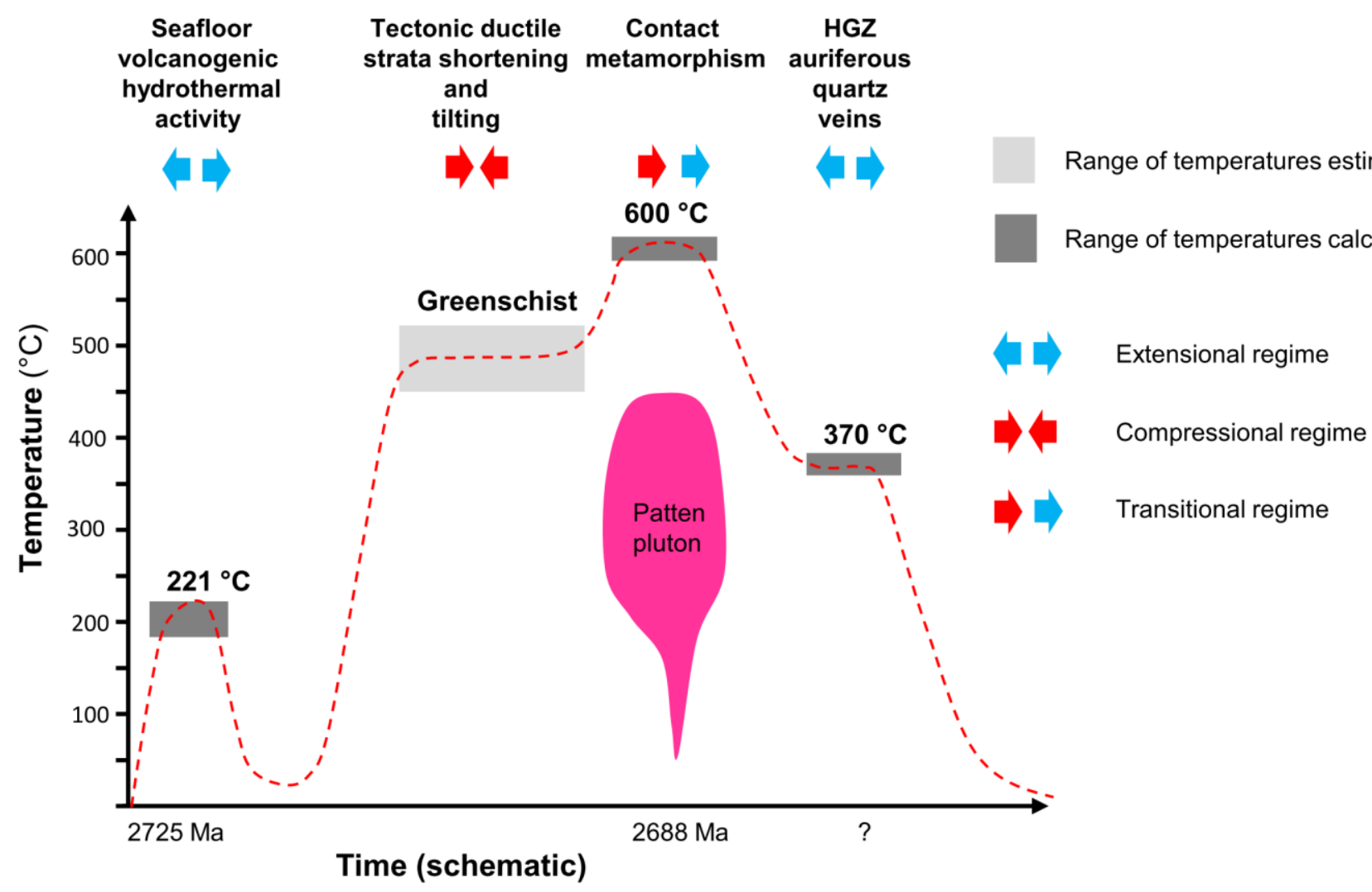

Figure 13. Tectono-thermal evolution of the mineralizing system, from primary volcanogenic ore to the late gold-rich quartz veins. Temperatures are constrained by sphalerite and amphibole geothermometers. Timeframe is given by the radiometric ages of rocks.

\subsection{Gold Solubility and Fluid Source}

For classical orogenic gold deposits, gold is transported mostly by HS- complexes, where its solubility is principally controlled by $\mathrm{pH}$ and redox (oxygen fugacity) conditions and concentration of reduced sulfur (e.g., [37,38,44]). At Perron, the potential solubility of the mineralizing fluids can be estimated using various diagrams at $370{ }^{\circ} \mathrm{C}$ for determin- 
ing the fugacity of sulfur (Figure 14A) and oxygen (Figure 14B), and the gold solubility (Figure 14C). Although the $\mathrm{pH}$ remains undetermined (Figure 14C), it can be approximated by the mineral assemblage of the gold-bearing veins: pyrite with calcite, local pyrrhotite without magnetite, all together are suggestive of neutral $\mathrm{pH}$ conditions (Figure 14C). As gold solubility is higher with increasing temperature (e.g., [38,45-47]), the interpreted conditions for aqueous gold solubility $\left(100\right.$ to $1000 \mathrm{ppb}$ at $\left.350{ }^{\circ} \mathrm{C}\right)$ are within the expected upper range for orogenic gold deposits [47].

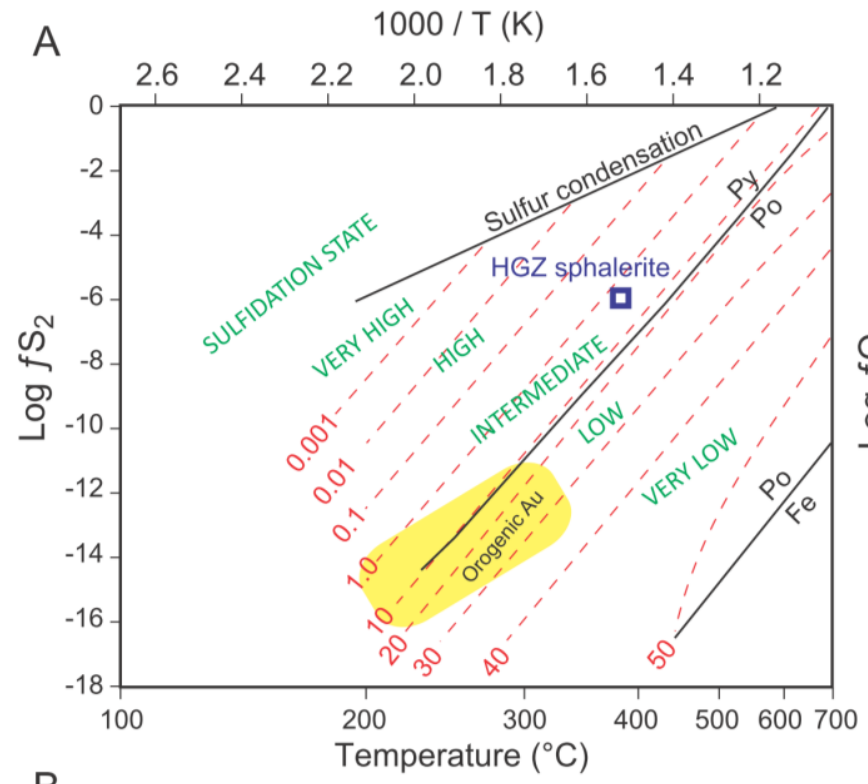

C
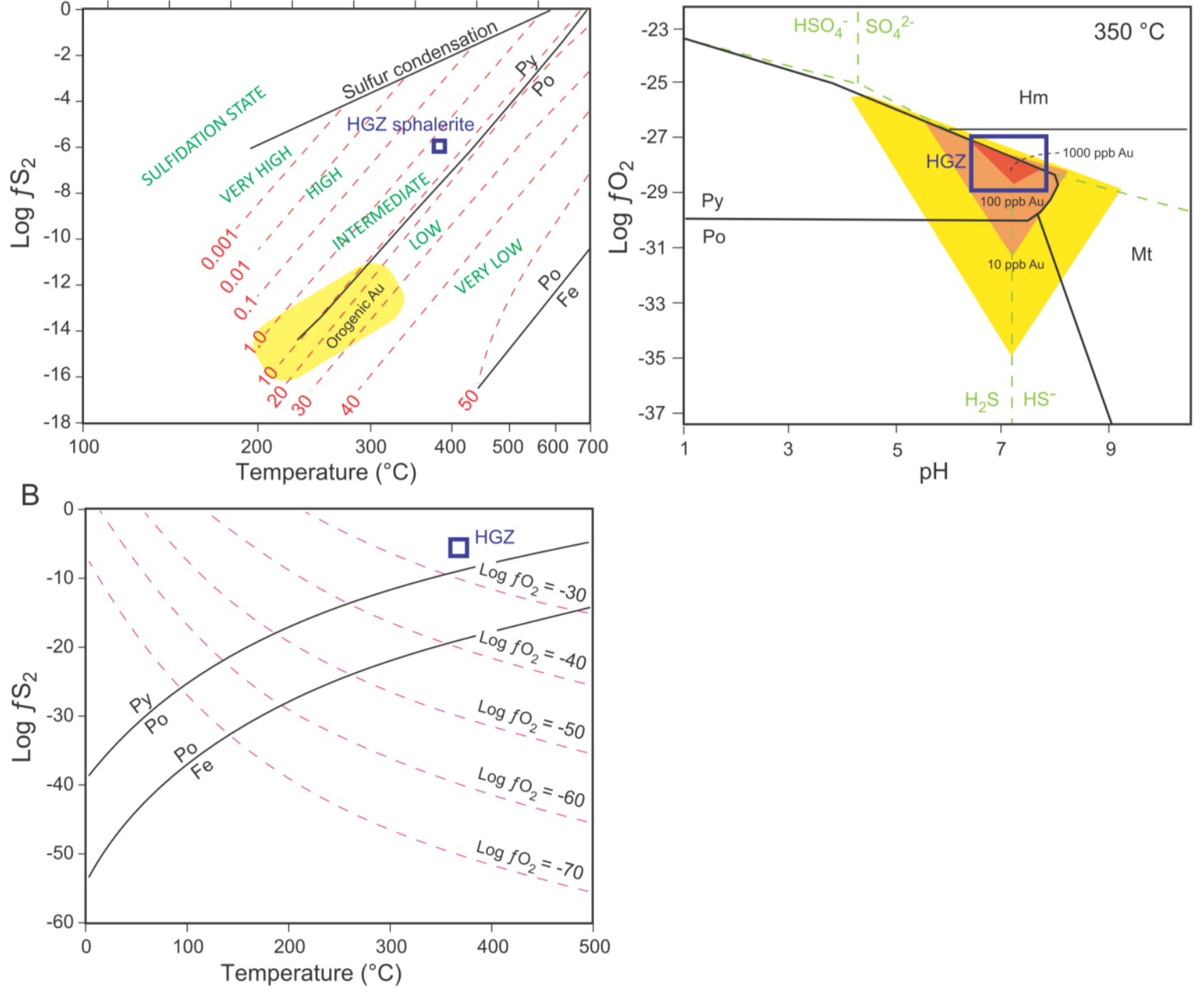

Figure 14. Geochemical diagrams for deciphering mineralizing conditions. (A) Log $\mathrm{fS}_{2}$ versus temperature diagram ([1] and reference therein), illustrating sulfidation states (in green) of the hydrothermal fluids, stable iron-sulfide mineral assemblages, $\mathrm{FeS}$ (mol\%) content of sphalerite (in red), and the field of orogenic gold deposits. The blue square is the HGZ sphalerite composition determined by LA-ICP-MS at $370{ }^{\circ} \mathrm{C}$ indicating a value of $\log \mathrm{fS}_{2}=-6$. (B) Temperature vs. $\mathrm{Log} \mathrm{fS}_{2}$ diagram ([48] and references therein) for ore formed at pressure of $1 \mathrm{~kb}$ with stable iron-sulfide mineral assemblages. Dash lines represent natural limits of oxygen fugacity $\left(\mathrm{Log} \mathrm{fO}_{2}\right)$ estimated from natural buffer reactions. The blue square is the HGZ plot of $\log \mathrm{fS}_{2}=-6$ at $370{ }^{\circ} \mathrm{C}$ indicating a $\log \mathrm{fO}_{2}=-28$. (C) $\mathrm{Log} \mathrm{fO}_{2}$ vs. $\mathrm{pH}$ diagram at $350{ }^{\circ} \mathrm{C}$ and pressure of $1 \mathrm{~kb}$ showing the gold solubility fields of $\mathrm{Au}(\mathrm{HS})_{2}{ }^{-}[45-47,49]$. The blue square is the $\mathrm{HGZ}$ conditions at $\mathrm{Log} \mathrm{fO}_{2}=-28 \pm 1$ with an estimated neutral $\mathrm{pH}$ based on the mineralogical assemblage (see text), indicating that aqueous fluids are within the expected optimal gold solubility window. $\mathrm{Py}=$ pyrite, $\mathrm{Po}=$ pyrrhotite, $\mathrm{Mt}=$ magnetite, $\mathrm{Hm}=$ hematite . 
Simmons et al. [47] demonstrated that the maximal solubility of gold occurs at temperatures $>350{ }^{\circ} \mathrm{C}$ for orogenic gold deposits. At lower temperatures, the concentration of aqueous $S$ is reduced by fluid-rock buffering, hence reducing the gold carrying capacity of the fluids. Consequently, the determined temperature, fugacity of sulfur and oxygen, and $\mathrm{pH}$ are all optimal for providing the highest aqueous gold solubility. In addition, the interpreted aqueous solubility of gold also falls within or close to the field documented for most orogenic gold deposits [47].

Analytical data and petrographic observations indicate that fluid inclusions are almost devoid of water. $\mathrm{CO}_{2}$-rich and $\mathrm{H}_{2} \mathrm{O}$-poor fluid inclusions have been documented from some world-class gold districts and deposits, such as Red Lake [50], Ashanti [51], Tarkwa goldfield [52], Detour Gold, and Wona [53]. Nevertheless, these $\mathrm{CO}_{2}$-rich fluid inclusions are commonly mixed with aqueous-bearing fluid inclusions, which is not the case for the HGZ. The origin of these fluids is still debated [25,53,54]. Post-entrapment modifications, fluid unmixing (boiling), and primary $\mathrm{CO}_{2}$-rich fluids were proposed as explanations [55]. Since no post-entrapment modification is observed, such as necking, flattening, dismembering, or neonate inclusion (e.g., [56]), fluid inclusions are considered well-preserved. Boiling cannot be ruled out, but it implies the coexistence of aqueous and gaseous fluid inclusions along the same trails [26], which is not observed. Fluid inclusions are thus considered representative of the mineralizing fluid composition.

At Perron, gold mineralization is retrograde, formed at a median temperature of $370 \pm 31{ }^{\circ} \mathrm{C}$, well below the metamorphic peak recorded by rocks at $\sim 60{ }^{\circ} \mathrm{C}$ before the formation of the HGZ (Figure 13). Consequently, a regional metamorphic dehydration origin of the fluids at depth, commonly invoked for the classical orogenic gold deposit formation [37,57], appears unlikely, hence supporting the primary origin of water-devoid mineralizing fluids.

Fluid inclusions are rich in hydrocarbon-bearing volatiles $\left(\mathrm{CH}_{4}, \mathrm{C}_{2} \mathrm{H}_{6}\right)$, with variable concentrations of $\mathrm{CO}_{2}, \mathrm{~N}_{2}$, noble gas (He and $\mathrm{Ar}$ ) and $\mathrm{H}_{2} \mathrm{~S}$. A compilation of various gas fields [32] indicates that alkanes from the lightest to the heaviest are the dominant compound as follows: methane (45.6-95.7\%), ethane (2.78-21.2\%), butane $(0.4-9.8 \%)$, propane $(0.1-4.5 \%)$, and pentane (0.079-1.6\%). Other constituents include $\mathrm{CO}_{2}(0.2-43.8 \%), \mathrm{N}_{2}$ $(0.11-14.3 \%), \mathrm{H}_{2} \mathrm{~S}(0.1-15.3 \%)$, and traces of noble gas (He, Ar). Comparatively, mineralizing fluids at the $\mathrm{HGZ}$ have a similar composition with natural gas from producing fields, although richer in $\mathrm{CO}_{2}$ (Figure $8 \mathrm{C}$ ).

The lack of water also implies that $\mathrm{Au}$ and $\mathrm{Zn}$ were not transported as aqueous species. Hydrocarbons have been invoked for the formation of gold deposits, especially for those in sedimentary settings and formed at low temperatures, such as epithermal [58], Carlintype [59], and even in the Giant Witwatersrand district [60-62]. Petroleum-phase gold transport is now considered as an efficient ore-forming process based on experimental data $[63,64]$. Au and $\mathrm{Zn}$ abundance in crude oils increases from 100 to $250{ }^{\circ} \mathrm{C}$, peaking at $\sim 200-250{ }^{\circ} \mathrm{C}$ (50 ppb for $\mathrm{Au}$ ) and decreasing at $>250-300{ }^{\circ} \mathrm{C}$ [65]. For $\mathrm{Zn}$, the maximal solubility reaches $\sim 25 \mathrm{ppm}$ at $200^{\circ} \mathrm{C}$ [65], which is about 100 time more than the solubility in low chloride aqueous solution [66]. Although largely qualitative and at lower temperatures $\left(<250{ }^{\circ} \mathrm{C}\right)$ than the interpreted HGZ formation, these results highlight the potential of hydrocarbon-rich fluids to mobilize and concentrate $\mathrm{Au}$ and $\mathrm{Zn}$.

Fluid inclusions were routinely analyzed for gaseous light hydrocarbons, such as methane $\left(\mathrm{CH}_{4}\right)$ and ethane $\left(\mathrm{C}_{2} \mathrm{H}_{6}\right)$, whereas liquid petroleum is a complex mixture of linear and cyclic hydrocarbons from C5 to C17 (e.g., [67]). To better support hydrocarbon contains, samples with the highest level of volatile liberated from routine analyses (samples RC-16 and RC-18, Supplementary Materials, Table S2) were reanalyzed for testing the presence of heavier alkanes by monitoring indicative AMU $(27,28,29,43,57,72)$ by the mass spectrometer. Results are conclusive for significant contents of butane (AMU 43) and possible propane, but other organic compounds in fluid inclusions remain to be identified.

Our data cannot prove the direct involvement of liquid petroleum for transporting gold and zinc. Nonetheless, liquid petroleum is unlikely to occur at moderate tempera- 
tures $\left(370{ }^{\circ} \mathrm{C}\right)$ as recorded for the HGZ formation, because the thermal cracking of liquid petroleum into lighter gaseous hydrocarbon phases begin at $\sim 150{ }^{\circ} \mathrm{C}[68]$ with a total gasification at $>220^{\circ} \mathrm{C}$ [69]. Consequently, the high solubility documented for $\mathrm{Au}$ and $\mathrm{Zn}$ in liquid crude oil [65] should be in gaseous hydrocarbon phases at $>200{ }^{\circ} \mathrm{C}$. Nevertheless, the specific bonding between gold and liquid hydrocarbons remains to be established, but the thiol group (-SH) is the most likely $[63,64]$. The HGZ contains sphalerite in percentage and lesser pyrite, indicating a high concentration of sulfur available in the fluids. $\mathrm{H}_{2} \mathrm{~S}$ is also recorded in fluid inclusions for some samples (Figure 8A). Furthermore, an intermediate sulfidation state $\left(\log f \mathrm{~S}_{2}=-6\right)$ is determined (Figure 14A). All of these imply a significant content of sulfur, possibly occurring as thiol in the mineralizing fluid.

Within hydrocarbon-rich fluids, gold can also be transported as colloidal nanoparticles, a mechanism invoked to account for forming exceptionally rich gold mineralizations [70-72]. Colloids can contain very high concentrations of Au in suspension. A key parameter for colloidal transport is the presence of sulfur and organic components (e.g., $\mathrm{NH}_{3}, \mathrm{CO}$, thiol, organic ligands, etc.) in the fluids for keeping gold under $\mathrm{Au}^{0}$ [73]. Experiments [73] showed that concentrations of gold as colloids in the solutions are up to $\sim 95 \mathrm{ppm}$ and colloidal nanoparticles can be stable up to $350{ }^{\circ} \mathrm{C}$ (limit of the experiment). As for hydrocarbon-metal complexes, further experimental data for colloidal gold transport are needed. Nevertheless, the unique composition of the mineralizing fluids, with their theoretical higher capacities for carrying gold, is considered a key parameter accounting for the richness of the HGZ.

The erratic content of water (Figures 3 and 8 ) in the fluids could be explained by earlier aqueous fluids necessary to form the quartz veins, the chlorite ribbons, and the pyrites Py1. It is possible, although not observed petrographically, that rare primary water-rich fluid inclusions have been preserved and analyzed (Figure 8). These aqueous fluids carried some gold as indicated by the LA-ICP-MS analyses of pyrites Py1 (Figure 9A, Supplementary Materials, Table S3) and by the established gold solubility (Figure 14C). Nevertheless, the aqueous fluids cannot alone account for the gold richness of the HGZ.

Hydrocarbons in Archean rocks, although very rare, may have a conventional biogenetic origin, generated by the metamorphism of black shales rich in organic matter (e.g., [53]). In the present case, since mineralization is formed later than the metamorphic peak (Figure 13), an abiotic deep-sourced hydrocarbon origin appears more likely (e.g., [74-76]). Abiotic hydrocarbons form at depth from inorganic reactions and migrate in the upper crust along crustal faults. It is out of the topic to discuss abiotic hydrocarbon formation, as it is still debated. Helium contents of fluid inclusions also support a deep-sourced degassing as documented along active regional faults (e.g., [77-79]). It should be mentioned that He was not previously documented from orogenic gold deposits analyzed by the same apparatus, for deposits ranging in age from Meso-Archean to Cretaceous $[53,54,80]$. It is thus considered that late retrograde fluids associated with the formation of the HGZ are atypical, even if physicochemical conditions are comparable to other orogenic gold deposits [47].

\subsection{Potential Source of Gold}

Exceptional high-grade mineralization in the HGZ may indicate that gold availability for saturating the hydrothermal fluids was not a limiting factor to the formation of a gold deposit (e.g., [37]). The presence of volcanogenic gold-bearing mineralization, occurring within the Central Polymetallic Zone, but also locally in the various gold zones (Figure 1), can be considered as a prime source for potential gold remobilization in later quartz veins. This hypothesis involves the expulsion of gold and trace metals from primary pyrites by transformation to pyrrhotite during prograde metamorphism $[81,82]$ deeper in the stratigraphic succession. This concept is supported by the similarity between the pyrite signature in the quartz veins with primary nodular pyrites in shales [20,83-86]. As, Sb, $\mathrm{Se}, \mathrm{Te}, \mathrm{Hg}$, and $\mathrm{Bi}$, which are pathfinder elements for orogenic gold deposits [57], are 
commonly used for such a comparison, as they are solubilized by HS- ligands like Au in classical orogenic gold deposits.

Analyses of primary gold-bearing volcanogenic pyrites were performed for such a comparison. Volcanogenic pyrites are quite different compared to HGZ pyrites and have heterogeneous trace element compositions (Figure 9C), a feature related in part to their temperature of formation $[19,34]$. Consequently, they are not as chemically homogeneous as nodular pyrites resulting from bacterial reduction in seawater, hence rendering comparison more difficult.

Conversely, gold-bearing primary nodular pyrites share a similar normalized pattern with HGZ pyrites, from $\mathrm{Au}$ to $\mathrm{Cu}$ (Figure 9D), whereas euhedral pyrites have a similar pattern from $\mathrm{Zn}$ to Mo. Most pathfinder elements, such as $\mathrm{As}, \mathrm{Se}, \mathrm{Te}, \mathrm{Bi}$, and $\mathrm{Hg}$, except $\mathrm{Sb}$, in the nodular pyrites are comparable in concentration to the HGZ, suggesting a possible source for gold at depth, according to the black shale model $[53,54,80-82,87]$. Of interest, it is $\mathrm{Cu}$ depletion by factors of 100 to 1000 times that is recorded by all pyrites (Figure 9D), supporting the hypothesis that these unusual $\mathrm{Cu}$-depleted nodular pyrites can be the deep source for gold in the HGZ. Graphitic shales should also be a potential source for hydrocarbons, but the post-metamorphic formation of the HGZ is challenging for supporting such a hypothesis.

Nevertheless, our fluid data imply that gold was transported mostly in nonaqueous solutions. Consequently, the solubility of pathfinder metals may be totally different, hence rendering the comparison of pyrites inapplicable for deciphering a potential gold source. Finally, the importance of volcanogenic gold pre-enrichment cannot be ruled out for the formation of the HGZ, but our data cannot support such an interpretation.

\section{Conclusions}

Various hypotheses were tested to account for the high-grade gold mineralization in the HGZ. Visible gold is associated with sphalerite precipitated at about $\sim 370{ }^{\circ} \mathrm{C}$ during exhumation of verticalized host rocks having recorded contact metamorphism at $\sim 600^{\circ} \mathrm{C}$. Pyrite chemistry is comparable to classical orogenic gold deposits from the Abitibi belt, without indication of a possible magmatic fluid and gold contribution. The established physicochemical conditions, which are optimal for aqueous gold solubility, are also typical of orogenic gold deposits. The most striking outcome is the lack of water in the mineralizing fluids, implying that gold was not transported under aqueous complexes as typical for orogenic deposits. Rather, fluids are, to some extent, comparable to fossil gas, being composed mostly of $\mathrm{CO}_{2}$ and hydrocarbons (methane and ethane, and possibly butane and propane, and other unidentified organic compounds). It is thus interpreted that gold and zinc were transported mostly as hydrocarbon-phase metals or as colloidal gold nanoparticles, hence accounting for the high contents of gold and zinc in the HGZ.

Supplementary Materials: The following are available online at https:/ /www.mdpi.com/article/ 10.3390/min11101066/s1, Table S1: Reference materials for LA-ICP-MS analyses, Table S2: Volatile analyses of fluid inclusion, Table S3: LA-ICP-MS analyses of pyrite, Table S4: LA-ICP-MS analyses of sphalerite with calculated temperature, Table S5: Microprobe amphibole analyses, with calculated temperature and pressure.

Author Contributions: Conceptualization, D.G. (Damien Gaboury); D.G. (Dominique Genna) and J.T.; data curation, D.G. (Damien Gaboury); formal analysis, D.G. (Damien Gaboury) and D.G. (Dominique Genna); funding acquisition, D.G. (Damien Gaboury); investigation, D.G. (Damien Gaboury), D.G. (Dominique Genna), M.B., J.A. and K.M.; methodology, D.G. (Damien Gaboury), D.G. (Dominique Genna) and J.A.; project administration, D.G. (Damien Gaboury); Supervision, D.G. (Damien Gaboury); validation, D.G. (Damien Gaboury), D.G. (Dominique Genna), M.B. and J.A.; writing—original draft, D.G. (Damien Gaboury); writing—review \& editing, D.G. (Damien Gaboury), D.G. (Dominique Genna), J.T., M.B., J.A. and K.M. All authors have read and agreed to the published version of the manuscript. 
Funding: Analytical works were supported by internal funding from UQAC to D.G. (Damien Gaboury). Field work and sampling were supported by Amex Exploration Inc. and Laurentia Exploration Inc.

Data Availability Statement: Not applicable.

Acknowledgments: All the staff at Laurentia Exploration Inc. and Services Miniers Geotech is thanked for their help provided during the 10 days sampling session on-site by the first author. Audrey Lavoie (UQAC) and Marc Choquette (Université Laval) generated the LA-ICP-MS and microprobe analyses respectively. B. Schulz (Technische Universität Bergakademie Freiberg) kindly provided the Excel spreadsheets for calculating amphibole geobarometric values. A special mention is given to the team at Vancouver Petrographics Ltd. for providing very quick thin section fabrication during the Covid-19 pandemic. The manuscript was improved by the comments of 4 anonymous reviewers, academic editor and Special Issue Editors (Antonia Cepedal and Mercedes Fuertes-Fuente).

Conflicts of Interest: The authors declare no conflict of interest.

\section{References}

1. Fontboté, L.; Kouzmanov, K.; Chiaradia, M.; Pokrovski, G.S. Sulfide Minerals in Hydrothermal Deposits. Elements 2017, 13, 97-103. [CrossRef]

2. Dubé, B.; Williamson, K.; McNicoll, V.; Malo, M.; Skulski, T.; Twomey, T.; Sanborn-Barrie, M. Timing of gold mineralization at Red Lake, northwestern Ontario, Canada: New constrainsts from U-Pb geochronology at the Goldcorp High-Grade zone, Red Lake mine, and the Madsen mine. Econ. Geol. 2004, 99, 1611-1641. [CrossRef]

3. Card, K.D. A review of the Superior Province of the Canadian Shield, a product of Archean accretion. Precambrian Res. 1990, 48, 99-156. [CrossRef]

4. Chown, E.H.; Daigneault, R.; Mueller, W. Tectonic evolution of the Northern Volcanic Zone, Abitibi belt, Quebec. Can. J. Earth Sci. 1992, 29, 2211-2225. [CrossRef]

5. Gaboury, D. Geochemical approaches in the discrimination of synvolcanic intrusions as a guide for volcanogenic base metal exploration: Example from the Abitibi belt, Canada. Appl. Earth Sci. 2006, 115, 71-79. [CrossRef]

6. Robert, F.; Poulsen, K.H. World-class Archaean gold deposits in Canada: An overview. Aust. J. Earth Sci. 1997, 44, 329-351. [CrossRef]

7. Dubé, B.; Mercier-Langevin, P.; Ayer, J.; Pilote, J.-L.; Monecke, T. Gold Deposits of the World-Class Timmins-Porcupine Camp, Abitibi Greenstone Belt, Canada; Special Publication; Society of Economic Geologists: Littleton, CO, USA, 2020; Volume 23, pp. 53-80.

8. Rodney, A.L.; Weihed, P. Global comparisons of volcanic-associated massive sulphide districts. Geol. Soc. Spec. Publ. 2002, 204, 13-37.

9. Gaboury, D.; Pearson, V. Rhyolite Geochemical Signatures and Association with Volcanogenic Massive Sulfide Deposits: Examples from the Abitibi Belt, Canada. Econ. Geol. 2008, 103, 1531-1562. [CrossRef]

10. Lafrance, B.; Mueller, W.U.; Daigneault, R.; Dupras, N. Evolution of a submerged composite arc volcano: Volcanology and geochemistry of the Normétal volcanic complex, Abitibi greenstone belt, Québec, Canada. Precambrian Res. 2000, 101, $277-311$. [CrossRef]

11. Mortensen, J.K. U-Pb gechronology of the eastern Abitibi Subprovince. Part 1: Chibougamau-Matagami-Joutel. Can. J. Earth Sci. 1993, 30, 11-28. [CrossRef]

12. Barrett, T.J.; Ayer, J.A.; Ordóñez-Calderón, J.C.; Hamilton, M.A. Burntbush-Normétal volcanic belt, Abitibi greenstone belt, Ontario-Quebec: Geological Mapping and Compilation Project, Discover Abitibi Initiative. In Geological Mapping and Compilation of the Burntbush-Normétal Volcanic Belt, Abitibi Greenstone Belt, Ontario-Quebec, Miscellaneous Release-Data 299; Ontario Geological Survey: Sudbury, ON, Canada, 2013; 135p.

13. Teasdale, N. Regional Study of Geochemical Alteration Associated with the Normétal Deposit Abitibi Greenstone Belt, Québec. Master's Thesis, École Polytechnique, Montreal, QC, Canada, 1993; 160p.

14. Lesher, C.M.; Goodwin, A.M.; Campbell, I.H.; Gorton, M.P. Trace-element geochemistry of ore-associated and barren, felsic metavolcanic rocks in the Superior Province, Canada. Can. J. Earth Sci. 1986, 23, 222-237. [CrossRef]

15. Zhang, Q.; Machado, N.; Ludden, J.N.; Moore, D. Geotectonic Constraints from U-Pb Ages for the Blake River Group, the Kinojevis Group and the Normetal Mine Area, Abitibi, Quebec. Program and Abstract; MAC/AMC: Edmonton, AB, Canada, 1993 ; p. A-114.

16. Lafrance, B. Reconstruction d'un Environnement de Sulfures Massifs Volcanogènes Déformés: Exemple Archéen de Normétal, Abitibi. Unpublished. Ph.D. Thesis, Université du Québec à Chicoutimi, Chicoutimi, QC, Canada, 2003; 362p.

17. Robert, F.; Poulsen, K.H. Vein Formation and deformation in greenstone gold deposits. Rev. Econ. Geol. 2001, 13, 111-155.

18. Gaboury, D.; Keita, M.; Guha, J.; Lu, H.-Z. Mass spectrometric analysis of volatiles in fluid inclusions decrepitated by controlled heating under vacuum. Econ. Geol. 2008, 103, 439-443. [CrossRef]

19. Genna, D.; Gaboury, D. Deciphering the Hydrothermal Evolution of a VMS System by LA-ICP-MS Using Trace Elements in Pyrite: An Example from the Bracemac-McLeod Deposits, Abitibi, Canada, and Implications for Exploration. Econ. Geol. 2015, 110, 2087-2108. [CrossRef] 
20. Augustin, J.; Gaboury, D. Multi-stage and multi-sourced fluid and gold in the formation of orogenic gold deposits in the world-class Mana district of Burkina Faso-Revealed by LA-ICP-MS analysis of pyrites and arsenopyrites. Ore Geol. Rev. 2019, 104, 495-521. [CrossRef]

21. Frenzel, M.; Hirsch, T.; Gutzmer, J. Gallium, germanium, indium, and other trace and minor elements in sphalerite as a function of deposit type-A meta-analysis. Ore Geol. Rev. 2016, 76, 52-78. [CrossRef]

22. Locock, A.J. An Excel spreadsheet to classify chemical analyses of amphiboles following the IMA 2012 recommendations. Comput. Geosci. 2014, 62, 1-11. [CrossRef]

23. Zenk, M.; Schulz, B. Zoned Ca-amphiboles and related P-T evolution in metabasites from the classical Barrovian metamorphic zones in Scotland. Miner. Mag. 2004, 68, 769-786. [CrossRef]

24. Boullier, A.-M.; Robert, F. Palaeoseismic events recorded in Archaean gold-quartz vein networks, Val d'Or, Abitibi, Quebec, Canada. J. Struct. Geol. 1992, 14, 161-179. [CrossRef]

25. Ridley, J.R.; Diamond, L.W. Fluid chemistry of orogenic lode gold deposits and implications for genetic models. Rev. Econ. Geol. 2000, 13, 146-162.

26. Wilkinson, J.J. Fluid inclusions in hydrothermal ore deposits. Lithos 2001, 55, 229-272. [CrossRef]

27. Bodnar, R.J.; Lecumberri-Sanchez, P.; Moncada, D.; Steele-MacInnis, M. Fluid Inclusions in Hydrothermal Ore Deposits. In Treatise on Geochemistry, 2nd ed.; Holland, H.D., Turekian, K.K., Eds.; Elsevier: Oxford, UK, 2014; Volume 13, pp. 119-142.

28. Li, X.-H.; Klyukin, Y.I.; Steele-MacInnis, M.; Fan, H.-R.; Yang, K.-F.; Zoheir, B. Phase equilibria, thermodynamic properties, and solubility of quartz in salineaqueous-carbonic fluids: Application to orogenic and intrusion-related gold deposits. Geochim. Cosmochim. Acta 2020, 283, 201-221. [CrossRef]

29. Tuba, G.; Kontak, D.J.; Choquette, B.G.; Pfister, J.; Hastie, E.C.G.; van Hees, E.H.P. Fluid diversity in the gold-endowed Archean orogenic systems of the Abitibi greenstone belt (Canada) I: Constraining the PTX of prolonged hydrothermal systems. Ore Geol. Rev. 2021, 135, 104221. [CrossRef]

30. Yardley, B.W.D.; Bodnar, R.J. Fluids in the continental crust. Geochem. Perspect. 2014, 3, 123. [CrossRef]

31. Prokofiev, V.Y.; Naumov, V.B. Physicochemical Parameters and Geochemical Features of Ore-Forming Fluids for Orogenic Gold Deposits Throughout Geological Time. Minerals 2020, 10, 50. [CrossRef]

32. Ismail, O.S.; Umukoro, G.E. Modelling combustion reactions for gas flaring and its resulting emissions. J. King Saud Univ. Eng. Sci. 2014, 28, 130-140. [CrossRef]

33. Genna, D.; Gaboury, D.; Azevedo, C.; Jébrak, M. Identifying a magmatic-hydrothermal contribution in Archean auriferous mineralization using pyrite chemistry. In Proceedings of the GSA2020 Connects Online, Boulder, CO, USA, 26-30 October 2020.

34. Grant, H.L.J.; Hannington, M.D.; Petersen, S.; Frische, M.; Fuchs, S.H. Constraints on the behavior of trace elements in the actively-forming TAG deposit, Mid-Atlantic Ridge, based on LA-ICP-MS analyses of pyrite. Chem. Geol. 2018, $498,45-71$. [CrossRef]

35. Gerya, T.V.; Perchuk, L.L.; Triboulet, C.; Audren, C.; Sez'ko, A.I. Petrology of the Tumanshet Zonal Metamorphic Complex, Eastern Sayan. Petrology 1997, 5, 503-533.

36. Hawthorne, F.C.; Oberti, R.; Harlow, G.E.; Maresch, W.V.; Martin, R.F.; Schumacher, J.C.; Welch, M.D. Nomenclature of the amphibole supergroup. Am. Miner. 2012, 97, 2031-2048. [CrossRef]

37. Gaboury, D. Parameters for the formation of orogenic gold deposits. Appl. Earth Sci. 2019, 128, 124-133. [CrossRef]

38. Williams-Jones, A.E.; Bowell, R.J.; Migdisov, A.A. Gold in solution. Elements 2009, 5, 281-287. [CrossRef]

39. Wagner, T.; Fusswinkel, T.; Wälle, M.; Heinrich, C.A. Microanalysis of fluid inclusions in crustal hydrothermal systems using laser ablation methods. Elements 2016, 12, 323-328. [CrossRef]

40. Fusswinkel, T.; Wagner, T.; Sakellaris, G. Fluid evolution of the Neoarchean Pampalo orogenic gold deposit (E Finland): Constraints from LA-ICPMS fluid inclusion microanalysis. Chem. Geol. 2017, 450, 96-121. [CrossRef]

41. Hastie, E.C.G.; Kontak, D.J.; Lafrance, B. Gold remobilization: Insights from gold deposits in the Archean Swayze Greenstone Belt, Abitibi Subprovince, Canada. Econ. Geol. 2020, 115, 241-277. [CrossRef]

42. Voisey, C.R.; Willis, D.; Tomkins, A.G.; Wilson, C.J.L.; Micklethwaite, S.; Salvemini, F.; Bougoure, J.; Rickard, W.D.A. Aseismic refinement of orogenic gold systems. Econ. Geol. 2020, 115, 33-50. [CrossRef]

43. Gaboury, D.; Ore Sanchez, C. Electrochemical gold precipitation to explain extensive vertical and lateral mineralization in the world-class Poderosa-Pataz district, Peru. Terra Nova 2020, 32, 97-107. [CrossRef]

44. Pokrovski, G.S.; Akinfiev, N.N.; Borisova, A.Y.; Zotov, A.V.; Kouzmanov, K. Gold speciation and transport in geological fluids: Insights from experiments and physical chemical modeling. Geol. Soc. Spec. Publ. 2014, 402, 9-70. [CrossRef]

45. Shenberger, S.D.; Barnes, H.L. Solubility of gold in aqueous sulfide solutions from $150-350{ }^{\circ}$ C. Geochim. Cosmochim. Acta 1989, 53, 269-278. [CrossRef]

46. Stefansson, A.; Seward, T.M. Gold(I) complexing in aqueous sulphide solutions to $500^{\circ} \mathrm{C}$ and 500 bar. Geochim. Cosmochim. Acta 2004, 68, 4121-4143. [CrossRef]

47. Simmons, S.F.; Tutolo, B.M.; Barker, S.L.L.; Goldfarb, R.J.; Robert, F. Hydrothermal Gold Deposition in Epithermal, Carlin, and Orogenic Deposits; Special Publication; Society of Economic Geologists: Littleton, CO, USA, 2020; Volume 23, pp. 823-845.

48. Pandit, D. Thermodynamic model for hydrothermal sulfide deposition in the paleoproterozoic granite ore system at Malanjkhand, India. Indian J. Geo-Mar. Sci. 2015, 44, 1697-1711. 
49. Gibert, F.; Pascal, M.-L.; Pichavant, M.M. Gold solubility and speciation in hydrothermal solutions: Experimental study of the stability of hydrosulphide complex of gold $\left(\mathrm{AuHS}^{\circ}\right)$ at 350 to $450^{\circ} \mathrm{C}$ and 500 bars. Geochim. Cosmochim. Acta 1998, 62, $2931-2947$. [CrossRef]

50. Chi, G.X.; Dubé, B.; Williamson, K.; Williams-Jones, A.E. Formation of the Campbell-Red Lake gold deposit by $\mathrm{H}_{2} \mathrm{O}-$ poor, $\mathrm{CO}_{2}$-dominated fluids. Miner. Depos. 2006, 40, 726-741. [CrossRef]

51. Mumm, A.S.; Oberthür, T.; Vetter, U.; Blenkinsop, T.G. High $\mathrm{CO}_{2}$ content of fluid inclusions in gold mineralisations in the Ashanti Belt, Ghana: A new category of ore forming fluids? Miner. Depos. 1997, 32, 107-118. [CrossRef]

52. Klemd, R.; Hirdes, W. Origin of an unusual fluid composition in Early Proterozoic Palaeoplacer and lode-gold deposits in Birimian greenstone terranes of West Africa. S. Afr. J. Geol. 1997, 100, 405-414.

53. Gaboury, D. Does gold in orogenic deposits come from pyrite in deeply buried carbon-rich sediments? Insight from volatiles in fluid inclusions. Geology 2013, 41, 1207-1210. [CrossRef]

54. Gaboury, D.; Nabil, H.; Ennaciri, A.; Maacha, L. Structural setting and fluid composition of gold mineralization along the central segment of the Keraf suture, Neoproterozoic Nubian Shield, Sudan: Implications for the source of gold. Int. Geol. Rev. 2020, 1-27. [CrossRef]

55. Klein, E.L.; Fuzikawa, K. Origin of the $\mathrm{CO}_{2}$-only fluid inclusions in the Palaeoproterozoic Carará vein-quartz gold deposit, Ipitinga Auriferous District, SE-Guiana Shield, Brazil: Implications for orogenic gold mineralisation. Ore Geol. Rev. 2010, 37, 31-40. [CrossRef]

56. Tarantola, A.; Diamond, L.W.; Stünitz, H. Modification of fluid inclusions in quartz by deviatoric stress I: Experimentally induced changes in inclusion shapes and microstructures. Contrib. Mineral. Petrol. 2010, 160, 825-843. [CrossRef]

57. Phillips, G.N.; Powell, R. Formation of gold deposits: A metamorphic devolatilization model. J. Metamorph. Geol. 2010, 28, 689-718. [CrossRef]

58. Crede, L.S.; Evans, K.A.; Rempel, K.U.; Brugger, J.; Etschmann, B.; Bourdet, J.; Reith, F. Revisiting hydrocarbon phase mobilization of $\mathrm{Au}$ in the Au-Hg McLaughlin Mine, Geysers/Clear Lake area, California. Ore Geol. Rev. 2020, 117, 103218. [CrossRef]

59. Emsbo, P.; Koenig, A.E. Transport of Au in petroleum: Evidence from the northern Carlin trend, Nevada. In Mineral Exploration and Research: Digging Deeper, Proceedings of the 9th Biennial SGA Meeting, Dublin, Ireland, 20-23 August 2007; Millpress: Dublin, Ireland, 2007; pp. 695-698.

60. Fuchs, S.; Schumann, D.; Williams-Jones, A.E.; Vali, H. The growth and concentration of uranium and titanium minerals in hydrocarbons of the Carbon Leader Reef, Witwatersrand Supergroup, South Africa. Chem. Geol. 2015, 393-394, 55-66. [CrossRef]

61. Fuchs, S.; Williams-Jones, A.E.; Jackson, S.E.; Przybylowicz, W.J. Metal distribution in pyrobitumen of the Carbon Leader Reef, Witwatersrand Supergroup, South Africa: Evidence for liquid hydrocarbon ore fluids. Chem. Geol. 2016, 426, 45-59. [CrossRef]

62. Fuchs, S.; Schumann, D.; Martin, R.F.; Couillard, M. The extensive hydrocarbon-mediated fixation of hydrothermal gold in the Witwatersrand Basin, South Africa. Ore Geolo. Rev. 2021, 138, 104313. [CrossRef]

63. Crede, L.S.; Evans, K.A.; Rempel, K.U.; Grice, K.; Sugiyama, I. Gold partitioning between 1-dodecanethiol and brine at elevated temperatures: Implications of Au transport in hydrocarbons for oil-brine ore systems. Chem. Geol. 2019, 504, 28-37. [CrossRef]

64. Crede, L.S.; Liu, W.; Evans, K.A.; Rempel, K.U.; Testemale, D.; Brugger, J. Crude oils as ore fluids: An experimental in-situ XAS study of gold partitioning between brine and organic fluid from 25 to $250{ }^{\circ}$ C. Geochim. Cosmochim. Acta 2019, 244, 352-365. [CrossRef]

65. Migdisov, A.; Guo, X.; Williams-Jones, A.; Sun, C.; Vasyukova, O.; Sugiyama, I.; Fuchs, S.; Pearce, K.; Roback, R. Hydrocarbons as ore fluids. Geochem. Perspec. Lett. 2017, 5, 47-52. [CrossRef]

66. Tagirov, B.; Seward, T.M. Hydrosulfide/sulfide complexes of zinc to $250{ }^{\circ} \mathrm{C}$ and the thermodynamic properties of sphalerite. Chem. Geol. 2010, 269, 301-311. [CrossRef]

67. Sephton, M.A.; Hazen, R.M. On the origins of deep hydrocarbons. Rev. Miner. Geochem. 2013, 75, 449-465. [CrossRef]

68. Zhao, W.; Zhang, S.; Zhang, B.; He, K.; Wang, X. New insight into the kinetics of deep liquid hydrocarbon cracking and its significance. Geofluids 2017, 11. [CrossRef]

69. Tsuzuki, N.; Takeda, M.; Suzuki, M.; Yokoi, K. The kinetic modeling of oil cracking by hydrothermal pyrolysis experiments. Inter. J. Coal Geol. 1999, 39, 227-250. [CrossRef]

70. Hough, R.M.; Noble, R.R.P.; Reich, M. Natural gold nanoparticles. Ore Geol. Rev. 2011, 42, 55-61. [CrossRef]

71. Petrella, L.; Thébaud, N.; Fougerouse, D.; Evans, K.; Quadir, Z.; Laflamme, C. Colloidal gold transport: A key to high-grade gold mineralization. Miner. Depos. 2020, 55, 1247-1254. [CrossRef]

72. McLeish, D.F.; Williams-Jones, A.E.; Vasyukova, O.V.; Clark, J.R.; Board, W.S. Colloidal transport and flocculation are the cause of the hyperenrichment of gold in nature. PNAS 2021, 118, e2100689118. [CrossRef] [PubMed]

73. Liu, W.; Chen, M.; Yang, Y.; Mei, Y.; Etschmann, B.; Brugger, J.; Johannessen, B. Colloidal gold in sulphur and citrate-bearing hydrothermal fluids: An experimental study. Ore Geol. Rev. 2019, 114, 103142. [CrossRef]

74. Sherwood Lollar, B.; Westgate, T.; Ward, J.; Slater, G.F.; Lacrampe-Couloume, G. Abiogenic formation of alkanes in the Earth's crust as a minor source for global hydrocarbon reservoirs. Nature 2002, 416, 522-524. [CrossRef]

75. Etiope, G.; Sherwood Lollar, B. Abiotic methane on Earth. Rev. Geophys. 2013, 51, 276-299. [CrossRef]

76. Reeves, E.P.; Fiebig, J. Abiotic Synthesis of Methane and Organic Compounds in Earth's Lithosphere. Elements 2020, 16, 25-31. [CrossRef] 
77. Doğan, T.; Sumino, H.; Nagao, K.; Notsu, K.; Tuncer, M.K.; Çelik, C. Adjacent releases of mantle helium and soil $\mathrm{CO}_{2}$ from active faults: Observations from the Marmara region of the North Anatolian Fault zone, Turkey. Geochem. Geophys. 2009, 10, 1-11.

78. Klemperer, S.L.; Kennedy, B.M.; Sastry, S.R.; Makovsky, Y.; Harinarayana, T.; Leech, M.L. Mantle fluids in the Karakoram fault: Helium isotope evidence. Earth Planet. Sci. Lett. 2013, 366, 59-70. [CrossRef]

79. Buttitta, D.; Caracausi, A.; Chiaraluce, L.; Favara, R.; Morticelli, M.G.; Sulli, A. Continental degassing of helium in an active tectonic setting (northern Italy): The role of seismicity. Sci. Rep. 2020, 10, 162. [CrossRef]

80. Gaboury, D.; Mackezie, D.; Craw, D. Fluid volatile composition associated with orogenic gold mineralization, Otago Schist, New Zealand: Implications of $\mathrm{H}_{2}$ and $\mathrm{C}_{2} \mathrm{H}_{6}$ for fluid evolution and gold source. Ore Geol. Rev. 2021, 133, 104086. [CrossRef]

81. Pitcairn, I.K.; Olivo, G.R.; Teagle, D.A.H.; Craw, D. Sulfide evolution during prograde metamorphism of the Otago and Alpine Schists, New Zealand. Can. Miner. 2010, 48, 1267-1295. [CrossRef]

82. Finch, E.G.; Tomkins, A.G. Pyrite-pyrrhotite stability in a metamorphic aureole: Implications for orogenic gold genesis. Econ. Geol. 2017, 112, 661-674. [CrossRef]

83. Thomas, H.V.; Large, R.R.; Bull, S.W.; Maslennikov, V.; Berry, R.F.; Fraser, R.; Froud, S.; Moye, R. Pyrite and pyrrhotite textures and composition in sediments, laminated quartz veins, and reefs at Bendigo gold mine, Australia: Insights for ore genesis. Econ. Geol. 2011, 106, 1-31. [CrossRef]

84. Large, R.R.; Bull, S.W.; Maslennikov, V.V. A carbonaceous sedimentary source-rock model for Carlin-type and orogenic gold deposits. Econ. Geol. 2011, 106, 331-358. [CrossRef]

85. Large, R.; Thomas, H.; Craw, D.; Henne, A.; Henderson, S. Diagenetic pyrite as a source for metals in orogenic gold deposits, Otago Schist, New Zealand. New Zealand. J. Geol. Geophys. 2012, 55, 137-149. [CrossRef]

86. Augustin, J.; Gaboury, D.; Crevier, M. The world-class Wona-Kona gold deposit, Burkina Faso. Ore Geol. Rev. 2016, 78, 667-672. [CrossRef]

87. Pitcairn, I.K.; Leventis, N.; Beaudoin, G.; Faure, S.; Guilmette, C.; Dubé, B. A metasedimentary source of gold in Archean orogenic gold deposits. Geology 2021, 49, 862-866. [CrossRef] 